\title{
Deformation at the frictional-viscous transition: Evidence for cycles of fluid-assisted embrittlement and ductile deformation in the granitoid crust
}

Philip Wehrens ${ }^{1,2}$, Alfons Berger ${ }^{1,{ }^{*}}$, Max Peters ${ }^{1,3}$, Thomas Spillmann ${ }^{4}$, Marco Herwegh ${ }^{1}$

\footnotetext{
${ }^{1}$ : Institut für Geologie, Universität Bern, Baltzerstr. 1+3, CH-3012 Bern, Switzerland

${ }^{2}$ : now at Swisstopo, Seftigenstr. 264, CH-3084 Wabern, Switzerland

3: now at Karlsruhe Institute of Technology, Institute of Applied Geosciences, Adenauerring 20b, 76131 Karlsruhe, Germany

4: NAGRA. Hardstrasse 73, CH-5430 Wettingen, Switzerland

*: corresponding author:

alfons.berger@geo.unibe.ch

Tel: $++41-31-6314990$
} 
Abstract

4 Mid-crustal deformation is classically characterized by the transition from ductile to brittle deformation

5 defining the frictional-to-viscous transition (FVT). Here we investigate an exhumed continental mid-

6 crustal basement section in order to envisage the relationship between ductile and brittle deformation at

7 the FVT. Our detailed study from km- to micro-scale shows that, under greenschist metamorphic

8 conditions, deformation is accommodated by a dense network of highly-localized ductile shear zones. In

9 the investigated case it is not quartz which defines the overall ductile deformation behavior but the viscous

10 granular deformation in shear zones with an ultrafine-grained polymineralic matrix consisting of quartz,

11 feldspar, sheet silicates and epidote. During viscous granular flow mass transfer processes under the

12 presence of fluids promote a chemo-mechanical mixing, resulting in grain size reduction and reaction

13 softening. Coeval with this ductile deformation, fluid-assisted embrittlement occurs, as indicated by

14 biotite-coated fractures, cataclasites and injection of non-cohesive polymineralic gouge material into

15 secondary fractures inside the host rock. The embrittlement during predominant ductile deformation

16 occurs in cycles, i.e. prolonged periods of slow viscous granular flow are interrupted by rapid brittle

17 deformation. We interpret this fluid-assisted cyclic embrittlement evidenced by injection of the fluidized

18 material into off-fault fractures as an alternative equivalent to pseudotachylites and as a microstructural

19 indicator for paleo-seismic activity. With exhumation and associated cooling, localized deformation

20 persists in the ultrafine-grained polymineralic shear zones but progressively transitions to cataclastic flow

21 and finally to pressure-dependent frictional flow; always showing cycles of slow interseismic flow and

22 fast seismic injection events. Overall, in the granitic crust of the Aar-massif, brittle and ductile

23 deformation coexist up to deformation temperatures of minimum $450^{\circ} \mathrm{C}$, indicating that the FVT has to be

24 placed in a rather wide range from $8 \mathrm{~km}$ up to $>18-20 \mathrm{~km}$ in the granitoid crust.

Keywords: frictional-viscous transition, cyclic embrittlement, viscous granular flow, high temperature friction, fluids 


\section{Introduction}

31 In a simplified view, the deformation behavior can be subdivided into an upper brittle part and a ductile lower part (Fig. 1), where the frictional-viscous transition (FVT) separates the two end-member deformation behaviors (Fig. 1b). Although any deformation mechanism has to be micro-physically based, its expression in form of flow laws and their extrapolation to crustal scale resulted in a rather broad use of the term FVT in literature. Three general applications of the term FVT can be discriminated: (1) a crustalscale depth interval (2) a bulk rheological deformation behavior and (3) a microstructural deformation style.

38 (1) The crustal-scale depth interval expresses the transition between the pressure-dependent Byerlee's

(3) On the microscale, the contemporaneous occurrence of frictional features (microcracks, fractures, cataclasites) with evidence for viscous deformation also indicates deformation at a FVT. While this type of transition is known as semi-brittle behavior in the case of monomineralic aggregates (e.g. Hirth et al. 1992), it is of particular importance in the case of polymineralic rocks, where often frictional deformation occurs in rigid phases embedded in a mechanically weak viscous matrix (e.g., Regenauer-Lieb and Yuen, 2003, 2004). Here the resulting rock strength of the composite aggregate strongly depends on the amount and spatial distribution of the different mechanical phases (e.g., Jordan 1987, Handy 1990, Bloomfield and Covey-Crump 1993, Kawamoto and Shimamoto 1998, Handy et al. 1999, Barnhoorn et al. 2005, Marques et al. 2010, Ji and Zhao 1993, Ji et al. 2003, 2004).

Moreover, by activating frictional deformation, the mechanically strong phases can undergo severe grain size reduction ending up in micron-sized polymineralic aggregates. The dramatic increase in grain surface areas enhances the efficiency of dissolution and precipitation processes (Rutter 1983), 

allows for grain rotations and the sliding of grains along each other (Fitzgerald and Stünitz 1993, Paterson 1995) and promotes mineral reactions (e.g., Menegon et al. 2013, Stünitz and Tullis 2001, Stünitz 1993). The combination of all these deformation processes in ultrafine-grained polymineralic aggregates is referred to as granular flow (Paterson, 1995, 2013). It depends on temperature, fluid content, grain size and the mineralogy (e.g., Wintsch and Yeh, 2013). At low and enhanced temperatures, respectively, different grain sizes and strain rates will result either in frictional granular flow (polymineralic cataclasites) or viscous granular flow (polymineralic mylonites; Fig. 1).

The application of (1-3) in nature depends on the spatial scale of interest and on the integrated time of deformation. Both, frictional and viscous deformations are based on discontinuous processes and can therefore be of temporary character. For example, frictional deformation can be activated at low to moderate strains in order to generate microfabrics suitable for high strain viscous deformation (Segall and Simpson, 1986; Christiansen and Pollard, 1997; Guermani and Pennacchioni, 1998; Herwegh and Kunze, 2002; Pennacchioni et al. 2006, Mancktelow and Pennacchioni, 2005; Pennacchioni, 2005; Pennacchioni and Mancktelow, 2007). In addition, building up of pore fluid pressures or strain rate weakening processes will induce switches from slow viscous to fast frictional processes manifesting seismic cycles (Fig. 1c, e.g., Handy et al. 2007, Fusseis and Handy 2008, Poulet et al., 2014). Hence the term FVT has a rather broad application and it has to be defined specifically, which time- and space-scales are addressed when dealing with it.

In this study we follow the arguments of Handy et al. (2007) and apply the term FVT to a depth range in the granitoid crust, in which the occurrence of both brittle and ductile processes occur. We investigate the deformation in granite, which we consider as important representatives for the middle continental crust (gneisses, granites). The study benefits from the relatively large volume of granitoid rocks exposed in the Aar-massif (Central Alps, Switzerland) and considers the fault rocks as natural laboratories for several reasons: (1) these rocks show simple compositions; (2) strain initially localized along steep shear zones within relatively isotropic host rocks at depths of $\sim 18-20 \mathrm{~km}$; and (3) during exhumation of the Aarmassif, strain further localized in these steep shear zones and progressively narrowed in width (Wehrens et al., in review). The latter allows a telescoped view of deformation behavior at different depths. We link field investigations and microstructural observations from these different depths and search for evidence for simultaneous activity of both frictional and viscous deformation processes as well as the depth limitations of the FVT. Special emphasis will be paid to the effect of fluids, given their importance for hydrofracturing, thermal-pressurization as well as mass transfer processes; all processes playing a major role in the FVT (e.g., Wintsch and Yeh, 2013). In contrast to the general assumption of quartz as the dominant rheology-defining mineral in the middle crust, we will demonstrate that the formation of ultrafine-grained polymineralic fault rocks (ultramylonites and fault gouges) is much more significant, given their high abundance and ability to reduce fault strengths from the surface down to depths of $20 \mathrm{~km}$. 


\section{Geological setting}

The Aar massif is located in central Switzerland and represents one of the external massifs of the Alps. It consists of polymetamorphic (pre-)Variscan basement rocks, which have been intruded by post-Variscan granitoid rocks around $298 \mathrm{Ma}$ (Abrecht, 1994; Schaltegger, 1994). The present study focuses on a transect through the Southern Central Aar massif (Haslital transect), where post-Variscan plutons are bounded by an aplitic boundary facies at the contact to the Paleozoic gneisses of the Grimsel Zone (Fig. 2; Stalder, 1964; Schaltegger, 1990).

Although deformation in the Paleozoic basement is long lasting (Proterozoic, Ordovician to Variscan and Alpine; Stalder 1964; Steck 1966, 1968, 1984; Schaltegger 1993; Schaltegger et al. 2003), the PostVariscan plutonic bodies only underwent Alpine deformation. Temperatures at the Northern rim of the Aar massif never exceeded $\sim 250^{\circ} \mathrm{C}$ (e.g., Bambauer et al., 2009), whereas at the Southern boundary

112 (Grimsel Pass), peak Alpine conditions were in the range of $450^{\circ} \mathrm{C}$ and $600 \mathrm{MPa}$ (Challandes et al., 2008;

113 Goncalves et al., 2012). This suggests that the Southern rim of the Aar massif, i.e. our study area, was at a

114 depth of about 18-20 km at its maximum. A multiphase Alpine deformation history, consisting of a phase

115 of compressional deformation under peak metamorphic conditions, followed by transpressional 116 deformation associated with retrogression and finally exhumation, affected the study area (Steck, 1968;

117 Challandes et al., 2008; Rolland et al., 2009; Wehrens, 2015). Strain is distributed in the Haslital along 118 many major shear zones (up to tens of meters wide and several $\mathrm{km}$ long) and a multitude of small discrete 119 shear zones $(<10 \mathrm{~cm}$ thickness $)$.

\section{Methods}

In the studied area, zones of localized deformation can be subdivided into brittle fault zones (fractured rock, cataclasite, breccia, fault gouge) and ductile shear zones. Given their both ductile and brittle nature, we refer to them in general as fault zones following the nomenclature of Schmid and Handy (1991). A field-based study was conducted in order to define the km-scale strain distribution of both brittle and ductile deformation zones. Detailed mapping of individual shear zones along and across their strain gradients provided information on their evolution and strain localization history. We focus on granitoid rocks, since they exclusively underwent Alpine deformation and their petrology is well known (Keusen et al., 1989; Schaltegger, 1989). Samples were taken across transects of ductile shear zones and brittle faults. In addition, drill core samples from fault gouges in the NAGRA Grimsel Test Site (GTS, Blechschmidt and Vomvoris, 2010) were analyzed. The structures in these samples were impregnated with a fluorescein doped resin prior to drilling in order to provide cohesion during the drilling process: preserving the in-situ microstructure and porosity of the fault gouges (Tanaka et al., 2014).

133 Microstructural analyses were carried out using optical light and scanning electron microscopy. The

134 dimensions and heterogeneity of the structures were identified on the micro-scale, which provided the basis for further microstructural and geochemical analyses. Fault gouge samples from the GTS, stabilized 
136 by the aforementioned approach, have been analyzed in under UV-microscope highlighting the 137 fluorescence of the infiltrated resin.

138 Phase and element distribution along brittle and ductile structures were investigated at the thin section scale. For this purpose, electron backscatter imaging and X-ray mapping with energy dispersive spectrometry (EDS) was carried out using a ZEISS EVO 50 scanning electron microscope with an acceleration voltage of $20 \mathrm{kV}$ and a beam current of 3-6 nA. Element maps were generated by EDAX $\mathrm{TEAM}^{\mathrm{TM}}$ software (Nylese and Anderhalt, 2014), and element quantification in oxide wt.\% was carried out. The created element maps and backscatter images were combined to determine the phases and were analyzed with ImageJ (http://imagej.nih.gov/ij/) to calculate their phase area percentages. Multiple areas were analyzed along each structure to control the quality of phase- and element quantification. Due to the heterogeneous nature of the structures, great care was taken in the choice of the location and size of the area, in order to represent the structures best. Adding the results for all areas along one individual structure defines a representative average. The total variation of the element wt.\% results is indicated with bars in the graphs. The total analyzed area for each structure ranged from 1.5 to $22 \mathrm{~mm}^{2}$. Each total analyzed area consists of multiple individual areas with sizes of 0.5-4.5 $\mathrm{mm}^{2}$. Each area contained in the order of 2001000 grains. For each hydrous phase, the water content was calculated on the basis of the obtained phase volume percentage and mineral stoichiometry (Deer et al., 1992).

153 Electron backscatter diffraction (EBSD) under low-vacuum conditions (10-15 Pa) was carried out on a 154 whole suite of oriented and polished thin sections. Here, additional polishing with colloidal silica was applied in order to reduce damage of the sample surface. Representative crystal orientation maps and corresponding pole figure diagrams were obtained from Euler angle measurements, using the TSL/Ametek OIM version 7.0 software package.

\section{Results}

\subsection{Spatial and temporal relationship of the investigated structures}

160 The units described above are cut by numerous shear zones, which can be well grouped from overprinting relationships and orientations (Wehrens, 2015, see section 2). The maximum formation depth of the exhumed shear zones is around $18-20 \mathrm{~km}$ and estimated maximum metamorphic temperatures are around $450^{\circ} \mathrm{C}$ (e.g., Goncalves et al., 2012). These shear zones are steeply inclined and show shear zone narrowing during the exhumation (retrograde) path. Over the past years, we have generated a comprehensive inventory of fault zones and associated fault rocks in the study area (Baumberger, 2015; Wehrens, 2015; Belgrano et al., 2016). Based on (1) large-scale shear zones and their overprinting relationships as well as (2) microstructures of frictional and viscous deformation, we will demonstrate that brittle deformation is not restricted to retrograde "young" deformation in shallow crustal levels (Fig. 1), 
170 deformation under peak metamorphic conditions, i.e. at high temperature (HT), we follow the following

171 strategy. Firstly the host rock as starting material of deformation will be introduced. We then present a

172 characterization of the aforementioned low temperature (LT) brittle structures. Subsequently, ductile shear

173 zones (formed under HT) will be shown before addressing the criteria and characteristics of high strain-

174 rate brittle faulting under HT peak Alpine metamorphic conditions.

$176 \quad$ 4.1.1 Host rocks

177 The host rocks are ranging from leucocratic granite (Central Aar granite) to granodiorite (Grimsel 178 granodiorite) and polymetamorphic granitoids (Grimsel zone; Stalder, 1964; Niggli, 1965; Keusen et al., 179 1989; Schaltegger, 1989). The granitoids show a primary compositional increase in biotite from 5 to

$18012 \mathrm{vol} \%$, which is a key for variation in the mechanical behavior (Wehrens et al., in review). The weakly 181 deformed granitoid rocks still show magmatic feldspars with their primary sizes (Table 1). Interstitial 182 quartz and biotite nests exist between the large magmatic feldspar grains. The quartz is mostly 183 dynamically recrystallized by subgrain rotation recrystallization and few remaining hosts grains show 184 undulose extinction. The average recrystallized grain size of the subgrains is around $180 \mu \mathrm{m}$ (Table 1). A 185 weak foliation may be present where biotite is aligned and connected between magmatic feldspar grains. 186 Epidote, most notably allanite, occurs as single crystals with a relative large grain size (Table 1).

\subsubsection{Low temperature brittle structures}

189 The low temperature cataclastic zones are clearly younger than the ductile shear zones (see below) as they 190 overprint their ductile precursors. Given the common reactivation of the ductile shear planes, they must 191 have formed under retrograde conditions. In the following, they are named low temperature cataclasites 192 (LT-cataclasite, Table 2). The non-cohesive gouge material and cataclasites is often washed out at the 193 surface by recent erosion (Fig. 3c). To enable the study of deformation microstructures and associated 194 deformation processes, these structures were stabilized in a complex approach in the underground GTS 195 laboratory (Grimsel Test Site) by drilling, resin injection and over-coring allowing the in-situ sampling. 196 The host granitoid shows magmatic feldspars being successively overprinted by ductile deformation as manifest by grain size reduction of feldspars as well as elongation and dynamic recrystallization of quartz 198 aggregates (Fig. 4e). The magmatic and mylonitic microstructures are dissected by individual fractures as 199 well as a polymineralic cataclasite (Fig. 4a-c). Clasts within the 1-2 mm wide cataclasites are angular and 200 consist of feldspar, quartz, mica and some epidote. The grain size in the cataclasite is much smaller than 201 that of the host rock (Table 1,2). This polymineralic cataclasite occurs even within fractures cutting 202 through monomineralic coarse-grained parts of the host rock (Fig. 4c). Furthermore, no overgrowth of mineral phases in the cataclasite is observed. UV-fluorescence light microcopy shows the resin-accessible porosity within the cataclastic matrix (Fig. 4b). Resin can also be found along the straight to slightly curved grain boundaries of the dynamically recrystallized quartz grains (Fig. 4d). Note that in both cases 
206 the occurrence of the fluorescent resin indicates open pore space is present in the nowadays subsurface 207 non-cohesive fault gouges within brittle fault zones.

\subsubsection{Localized ductile deformation}

210 Ductile shear zones range from $\mathrm{mm}$ to several meters width. Laterally, they can extend over several 211 kilometers. Inside the mylonites, feldspar clasts are reduced in size by brittle processes (Fig. 5a, b; Table 212 1, 2), and interstitial quartz domains become elongated by crystal plastic deformation (Fig. 5b), while 213 biotite is aligned parallel to the shear plane (Fig. 5a, b). With increasing strain, the size of feldspar grains

214 is further reduced. Quartz domains are more elongate and a polymineralic matrix of very fine-grained 215 recrystallized quartz, biotite, white mica and minor epidote develops (Fig. 5a-c). The vast majority of 216 ductile shear zones consist of ultramylonites with polymineralic composition, while monomineralic quartz 217 aggregates occur sparsely in the form of lenses or bands. The grain sizes within the polymineralic matrix 218 of such mylonites are order of magnitudes smaller as those of the surrounding gneisses (Table 1). Within 219 monomineralic quartz domains, few remnant (primary) quartz grains reveal undulose extinction patterns 220 and the presence of subgrains. Progressive subgrain formation leads to newly recrystallized quartz grains 221 (subgrain rotation recrystallization; Guillope and Poirier, 1979; Drury and Urai, 1990). The grain size in 222 these aggregates is around $100 \mu \mathrm{m}$ (area-weighted mean grain size; Figs. 5b, 6a). In most samples, 223 dynamic recrystallization of monomineralic quartz aggregates is nearly complete throughout the fabric 224 (Fig. 6a). All these observations infer subgrain rotation recrystallization as the dominant dynamic recrystallization process with a minor component of grain boundary migration being present as well. In order to define the deformation mechanisms in quartz, a characteristic, monomineralic quartz aggregate and a polymineralic layer were quantitatively analyzed (EBSD; Fig. 6a-c). The data are presented in a grain orientation map (Fig. 6a), which was calculated from Euler angles obtained from the EBSD

230 These monomineralic quartz aggregates typically reveal a moderate crystallographic preferred orientation

231 (CPO; Fig. 6c). The pole figure of the [c]-axis (0001) indicates a strong peripheral maximum (cluster), 232 rotated around $60^{\circ}$ with respect to the foliation $(f)$ following the sense of shear. In this aggregate, a [c]axis single girdle is developed. The $<\mathrm{a}>$ axes (11-20) consistently align subparallel to the stretching

234 lineation $(L)$. Rhomb $<\mathrm{a}>$ glide can also be identified, as some of the [c]-axes is concentrated between the 235 Y- and Z-axes (Fig. 6c). The fine-grained polymineralic layers are intercalated with biotite bands (Figs. $2365 \mathrm{~d}, 6 \mathrm{~d})$. In the case of the polymineralic layers, grain sizes of quartz vary between $10-80 \mu \mathrm{m}$ depending on 237 the degree of pinning by the other minerals (Fig. 6e, f). Both the quartz [c]-axes and $<\mathrm{a}>$ axes show 238 random distributions (Fig. 6g, h), clearly contrasting the CPOs of the monomineralic layers. 


\section{$240 \quad$ 4.1.4 High temperature brittle structures}

241 As will be demonstrated in the following, brittle structures exist at high temperatures, i.e. at conditions 242 similar to those described for the aforementioned ductile deformation. The relative ages are inferred from 243 field crosscutting relations (Fig. 7). This section presents the microstructural characteristics of these high244 temperature (HT) brittle structures.

245 The host rock fabric consists of magmatic feldspar and dynamically recrystallized quartz grains (see 246 section 4.1.1). Both of these features are cut by micro-fractures (Fig. 7b). They also cut through aggregates and individual grains and are filled with a polymineralic assemblage consisting of biotite, albite, white mica and epidote (Fig. 7b, c). Transgranular and intergranular fractures can be observed within the dynamically recrystallized quartz aggregates as indicated by biotite precipitates (Fig. 7c, d).

250 Hence, they are younger than dynamic recrystallization of quartz in these microstructural domains, but the 251 conditions of this brittle deformation were still within the mineral stability field of biotite.

252 Additionally, epidote-filled veins are observed parallel to the shear plane cutting through both the 253 magmatic feldspar clasts and recrystallized quartz aggregates. Ductile micro-shear zones developed along epidote-filled veins, which are defined by quartz and biotite recrystallization. In addition, cataclasis is observed at the margin of a decameter-scale shear zone (Fig. 8a). A cataclasite (HT-cataclasite) occurs within the least ductilely deformed part of the decameter-sized strain gradient of a shear zone (Fig. 8a). At the weakly deformed margin, the host rock is fractured in a similar fashion as seen in the LT-cataclasites.

258 The fractures in the host are composed of clasts surrounded by a fine-grained polymineralic matrix (Table 259 1). At several locations, smaller secondary fractures, which branch from the main cataclasite, cut into the 260 weakly deformed host rock (Fig. 7a, b). The fine-grained polymineralic matrix is also observed in 261 fractures passing through monomineralic host rock domains (Fig. 7b). The polymineralic matrix shows 262 very small grain sizes (Table 1; Fig. 8c, f). It is important to note, in contrast to the LT cataclasite 263 example, that biotite $(50-150 \mu \mathrm{m})$ is overgrowing the polymineralic matrix. This observation places the conditions of brittle cataclastic deformation into the mineral stability field of biotite (Fig. 8c).

265 Occasionally, micro-epidote veins cut this ultrafine polymineralic matrix (most obvious as white lines in 266 Fig 7c), again recording brittle deformation. At some localities within the ultrafine polymineralic matrix 267 these veins are even folded (Fig. 7d, f). This folding illustrates that viscous processes affected the fine268 grained matrix and veins, which both have a brittle origin.

\subsection{Chemical and mineralogical compositions of different tectonites}

271 We investigate LT-cataclasites, ductile shear zones and HT-cataclasites in detail. The selected 272 microstructural domains reflect a representative selection which is based on the inspection of a large series 273 of thin sections (Table 2). The detailed microstructural analyses revealed differences between the described structures and their mineralogical compositions. A LT-cataclasite and a ductile mylonite have

275 been studied within the Central Aar granite. The LT-cataclasite is compositionally similar to the granitic 
host rock (Figs. 9, 10, 11). The $\mathrm{K}_{2} \mathrm{O}$ to $\mathrm{SiO}_{2}$ ratio is higher for the cataclasite (Fig. 11). The water content within the LT-cataclasite $(0.4 \mathrm{wt} \%)$ is similar to that of the undeformed granitoid, which ignores potential water content within the pore space (Fig. 10b).

In contrast to the LT-cataclasite, the mylonite shows significant variations compared to the host granitic composition (Fig. 10a). An increase in mica within the mylonite relative to the weakly deformed Central Aar granite has been measured. Furthermore, the albite content decreased within the mylonite compared to the host. The mylonite shows a loss in $\mathrm{Na}_{2} \mathrm{O}$ and a gain in $\mathrm{K}_{2} \mathrm{O}, \mathrm{MgO}$ and to a lesser degree $\mathrm{Fe}_{2} \mathrm{O}_{3}$ compared to the host (Fig. 11). The calculated water content for the mylonites is $\sim 1 \mathrm{wt} \%$ and is therefore higher than in the undeformed Central Aar granite (Fig. 10b). Similar observations have been published for shear zones within the Grimsel granodiorite (Marquer et al., 1985; Goncalves et al., 2012).

Four samples were analyzed along a strain gradient inside the Grimsel Zone (Fig. 9). The gradient shows increasing strain over a distance of 40 meters from weakly deformed granitoid to an ultramylonite (Fig. 9a). The structures along the gradient consist of (i) an epidote-rich HT-cataclasite from the weakly deformed granitoid part. (ii) weakly sheared epidote white mica-rich bands and (iii) schistose granitoid band from the moderately deformed schistose granitoid with highly sheared epidote-albite-mica rich layers, and finally (iv) an ultramylonitic core (Fig. 9).

(i) The HT-cataclasite clearly differs from the Grimsel Zone granitoid composition and is dominated by albite and epidote (Figs. 10,11). The HT-cataclasite consists of almost 50 vol\% epidote compared to a few vol\% in the host rock. Furthermore, the HT-cataclasite sample has a low quartz content (6 vol\%) and almost no K-feldspar. Also the element wt.\% ratios are clearly different from the granitoid composition (Fig. 11). The HT-cataclasite shows higher values for $\mathrm{Na}_{2} \mathrm{O}, \mathrm{Al}_{2} \mathrm{O}_{3}$ and most clearly for $\mathrm{CaO}$. The $\mathrm{K}_{2} \mathrm{O}$ to $\mathrm{SiO}_{2}$ ratio is lower than for the granitoid composition. Furthermore, the sample is poor in $\mathrm{SiO}_{2}$ (Fig. 9c). The water content within the HT-cataclasite (1.2 wt\%) is higher than in the undeformed granitoid and mylonites (Fig. 10b).

(ii) The schistose granitoid band contains less mica and slightly more epidote although is generally similar to the granitoid host (Fig. 10). The element wt.\% shows a strong similarity with the Grimsel Zone host rock and no significant changes in elemental abundance can be noted (Fig. 11). The water content of $0.26 \mathrm{wt} . \%$ is lower than in the host and comparable to that of the Central Aar granite (Fig. $10)$.

(iii) The epidote white mica-rich band shows a markedly different composition to the Grimsel Zone granitoid (Figs. 9, 10). This band contains a large amount of epidote (23 vol\%) and white mica (17 vol\%). Furthermore, the quartz content is extremely low (4 wt.\%). The element wt.\% of $\mathrm{Na}_{2} \mathrm{O}, \mathrm{Al}_{2} \mathrm{O}_{3}$, $\mathrm{K}_{2} \mathrm{O}, \mathrm{CaO}$ for this area plots in between the host rock and the HT-cataclasite (Fig. 11). The water content of this second schistose area $(1.27 \mathrm{wt} . \%)$ is comparable to that of the HT-cataclasite (Fig. $10 b)$.

(iv) At the most strongly deformed part within the strain gradient, the ultramylonite displays an increase in white mica compared to the host rock and a marked decrease in K-feldspar (Figs. 9, 10). The 
element wt.\% of the various elements indicates no large differences between the ultramylonite and the host rock, although a slight loss of $\mathrm{K}_{2} \mathrm{O}$ can be noted (Fig. 11). The water content within the ultramylonite is around $1 \mathrm{wt} \%$, therefore higher than in the undeformed granitoid rocks and comparable to the water content of the mylonite (Fig. 10b).

Overall, higher water content for deformation structures compared to the undeformed rock is noted (Fig. $10 \mathrm{~b})$. The ductile mylonite and ultramylonite show an increase in mica content compared to the host rocks and a decrease in feldspar (Fig. 10a). The LT-cataclasite shows a similar composition to the host and no major change in major element chemistry. The HT-cataclasite is not comparable to the composition of the surrounding Grimsel Zone granitoid.

\section{Discussion}

This section discusses the interplay of grain size reduction, viscous and frictional deformation mechanisms and cyclic fast-brittle and slow-ductile deformation. We suggest that the presence of fluids particularly contributes to the associated mechanical and chemical deformation behavior. In the following discussion it will be crucial to discriminate between deformation occurring during the main Alpine HT metamorphic conditions and subsequent deformational overprint during retrograde cooling.

\subsection{Deformation mechanisms}

The main characteristics of the investigated fault rocks under both brittle and ductile deformation are attributed to a grain size reduction and a mechano-chemical phase mixing (e.g., Kruse and Stünitz, 1999; Linckens et al., 2015; Figs. 4, 5a-c, 8). During deformation, the grain-size of originally coarse grained (0.2 $-2 \mathrm{~mm}$ ) magmatic mineral phases like feldspar and quartz is dramatically reduced by up to three orders of magnitude as observed in all described tectonites (mylonite, ultramylonite, HT-cataclasite and LTcataclasite; Table 1). The associated progressive evolution into compositional layers in the mylonites/ultramylonites implies an important role of chemical processes during these deformation processes. In the following, we discuss the brittle and ductile deformation mechanisms and afterwards their spatial and temporal interplay.

\subsubsection{Low temperature cataclasites}

Within the LT-cataclasites, the original grain size is reduced to angular clasts of various sizes (Table 1). Although being partly affected by an earlier grain size reduction during preceding ductile deformation (e.g. subgrain rotation of dynamically recrystallized quartz, see below), deformation in these tectonites is controlled by purely brittle grain refinement and frictional flow as already described for many cataclasites (e.g., Rutter, 1986, Marone, 1998; Snoke et al., 1998; Keulen et al. 2007). Angular clasts ( $\mu \mathrm{m}$ - tens of $\mu \mathrm{m})$ are surrounded by an ultrafine-grained polymineralic matrix, which accommodated the cataclastic 
347 flow. In addition to this probably aseismic cataclastic flow, the gouge also experienced stages of fluidized 348 granular flow as made evident by the observed (i) granular texture, (ii) sharp contacts between gouge and 349 wall rock, (iii) sorting of grain size classes of clasts in fault-plane-parallel bands and (iv) the injection of 350 non-cohesive gouge into off-fault cracks in the host rock (see also Monzawa and Otsuki, 2003; Boullier et 351 al., 2009; Fondriest et al., 2013; Rowe et al. 2012; Rowe and Griffith, 2015). Particularly the injection 352 structures, the non-cohesive character of the gouge as well as the potentially laminar fluidized granular 353 flow point to fast processes under the presence of water and elevated pore fluid pressure at seismic rates at 354 shallow crustal levels. Note that the observed LT-microstructures and inferred deformation processes will 355 356

\subsubsection{Mylonites and ultramylonites}

358 Initial fracturing or the concentration of stress along pre-existing mechanical anisotropies forced strain to 359 localize in the ductile field, as already proposed in previous studies (Fig. 7; Mancktelow and Penniachioni 360 2005; Mancktelow and Penniachioni 2013, Wehrens et al., in review). Besides these strain nucleation 361 features, in the samples studied, additional strain-softening processes were activated. Quartz deforms in a 362 ductile manner by means of dislocation creep. The dominance of this deformation mechanism within 363 monomineralic quartz layers is identified based on the active slip systems combined with a 364 crystallographic preferred orientation (CPO) as well as typical subgrain rotation recrystallization 365 microstructures (Fig. 6a-c; e.g., Hirth and Tullis, 1992; Herwegh and Handy, 1996; Kilian et al., 2011). 366 The fabric is dominantly characterized by active basal and rhomb glide along the $<\mathrm{a}>$ axis (Schmid and 367 Casey, 1986), which is an indicator for deformation of quartz under greenschist facies conditions (e.g., 368 Schmid and Casey, 1986; Stipp et al., 2002).

369 Within the polymineralic domains of the ultramylonites, the weak CPO of quartz, the equiaxial small grain 370 sizes and the homogeneous mixing of the different phases within mylonitic layers suggest deformation by 371 viscous granular flow (diffusion creep) involving grain boundary sliding, dissolution and precipitation and 372 diffusive mass transfer processes (Fig. 6d-h, see also Fliervoet et al., 1997; Paterson, 1995). In our 373 samples, neo/re-crystallization of biotite, white mica, quartz and feldspar takes place. A volumetric 374 increase in the mica content as well as viscous granular flow in combination with mineral reactions and 375 mass transfer processes (e.g., Stünitz and Fitzgerald, 1993; Paterson, 1995; Menegon et al., 2013) allowed 376 for an enrichment of such mechanically weak phases in these high strain zones. A combination of grain 377 size softening and reaction softening therefore controls strain localization in these polymineralic tectonites 378 (Stünitz, 1998; Goncalves et al., 2012; Marsh et al., 2009). 


\subsubsection{High temperature cataclasites}

Similar to the LT-cataclasites, HT-cataclasites show reduced grain size and angular clasts of various sizes, which are embedded in an extremely fine-grained matrix (down to a few $\mu \mathrm{m}$; Table 1; Figs. 4, 8). Sharp contacts to wall rocks and grain size sorting in bands parallel to the fault plane are also present (Fig. 8a). Deformation is therefore controlled by brittle grain refinement and frictional granular flow (cataclastic flow). As already mentioned for the polymineralic ultramylonites, dilation in combination with dissolution-precipitation and mass transfer processes represents important strain accommodation processes during granular flow in these ultrafine-grained deformation products. Fluid-assisted injection of low viscosity gouge material into secondary fractures implies a complete embrittlement of the polymineralic aggregates and a loss in cohesion between grain contacts. In contrast to the non-cohesive LT-cataclasites, however, the HT-cataclasites were initially cohesive, as made evident by the intergrowth microstructures. Probably the presence of fluids in combination with earthquake shaking allowed the aggregates to fragment along the grain boundaries, promoting the injection of the at-that-time non-cohesive polymineralic gouge into the off-fault fractures (van der Elst et al., 2012; Rowe and Griffith, 2015). This brittle deformation must have occurred under HT-conditions, as indicated by the overgrowth of ultrafinegrained cataclastic matrix by biotite and the ductile folding of veinlets (Fig. 8). Given these high temperatures, non-cohesive grain boundaries have a low survival potential, requiring both fast embrittlement and injection processes.

\subsection{The role of fluids during brittle and ductile deformation}

Fluids play a crucial role in the development of the brittle and ductile fault rocks observed in this study (e.g., Etheridge et al., 1984; Marquer et al., 1985). On the one hand, fluids serve as transport media for mass transfer processes, on the other hand, the building up of pore fluid pressure increases the potential for hydrofracturing (e.g., Sibson, 1989; Cox, 2010) or ductile shear fracturing (Weinberg and RegenauerLieb, 2009). Principally three important questions need to be discussed with respect to our natural examples: (1) the potential presence or absence and amount of fluid at different stages of deformation, (2) the role of fluids for deformation mechanisms in the frictional and viscous field and (3) their implications for the resulting rheology. Despite numerous studies on the effect of dissolution-precipitation processes in carbonates (Rutter 1986), gypsum (de Meer et al. 1997) and phyllosilicates (Bos and Spiers 2001), to our knowledge yet no experimental data for granitic systems in general and for polymineralic ultramylonites in particular exist. Such knowledge would be crucial for absolute estimates on parameters in any flow law. In the following, we therefore have to restrict on a discussion of (1) and (2).

A variety of evidence exists for the presence of fluids during the entire evolution of the tectonites in the Aar massif (e.g., Gonclaves et al. 2012). In the following we treat the effects of fluids as a function of increasing depth. Chemical analyses have shown a similar mineralogical composition of both the LTcataclasite and their host rock, which implies a purely mechanical grain size reduction and phase mixing 
416 without the necessity of chemical reactions or mass transfer via fluids (Figs. 4a-c, 9c). Contrastingly, the 417 fine-grained polymineralic matrix within fractures in monomineralic host rock domains, points towards a 418 fluid-assisted injection of non-cohesive polymineralic material into the opening fractures (see Fig. 4c and 419 above). Both the injection structures of fault gouge material and the existence of the open fractures 420 illustrate the presence of fluids under conditions of LT- deformation.

421 Fluids as transport media play a peculiar role during mineral precipitation and mineral growth at elevated 422 deformation temperatures. For example, the quartz or epidote-albite veins, as well as the inter- and 423 transgranular fractures in the ductilely recrystallized quartz aggregates, filled with fine-grained biotite or polymineralic precipitates, indicate fluid-assisted fracturing and mass transfer at HT-conditions (Fig. 7bd). Also the significant chemical difference between HT-cataclasite and the granitoid host rock requires fluids as mass exchange media (Figs. 10, 11). During stages of low to intermediate pore fluid pressures, i.e. during stages of slow aseismic creep, these fluids promote the build up of cohesion in the polymineralic fine-grained matrices of the HT-cataclasites. Owing to their high surface areas, surfacecontrolled dissolution and precipitation processes become efficient under elevated temperatures. These chemico-physical conditions allow an enhanced coupled grain coarsening in the polymineralic domains (Herwegh et al. 2011 and references therein), leading to the build-up of renewed cohesion after each brittle HT-event. In this way, the mechanical character of the polymineralic matrices alternatingly changes between non-cohesive and cohesive. Last but not least, the injection structures of fine-grained polymineralic matrix into off-fault fractures, combined with the overgrowth of biotite, again prove the presence of fluid during cataclastic deformation under upper greenschist facies conditions (Fig. 8).

Besides the cataclasites, also the mylonites show evidence for deformation-assisted fluid flow and element transport. Element transport is illustrated by the higher $\mathrm{K}_{2} \mathrm{O}$ to $\mathrm{SiO}_{2}$ ratio of the mylonite compared to the host (Fig. 11; see also Marquer et al., 1985; Goncalves et al., 2012). During deformation by viscous granular flow (i.e. precipitation and dissolution, grain boundary sliding, creep cavitation) dynamic porosity is created at the micro-scale promoting fluid transport along grain boundary voids and intergranular cavities (Etheridge et al., 1984; Ree, 1991; Herwegh and Jenni, 2001; Fusseis et al. 2009; Menegon et al. 2015). Such advective fluid flow during viscous granular allows element transport and growth of new phases (Herwegh and Jenni, 2001; Goncalves et al., 2012; Menegon et al., 2015).

Altogether, these observations clearly indicate fluid activity plays a major role ranging from shallow and low to mid-crustal high temperature deformation. In the latter case, mass transfer processes become increasingly important with rising temperature. For fluid flux in the studied fault system two end-members have to be discriminated: (i) Stages of continuous and (i) discontinuous fluid in- and exfiltration. (i) The enrichment of $\mathrm{K}_{2} \mathrm{O}, \mathrm{SiO}_{2}$ and hydrous phases indicates an open system with infiltration of external fluids. Such infiltration may have occurred during continuous grain-scale processes (e.g. granular fluid pump of Fusseis et al. 2009). Fluid sources probably were dehydration reactions at lower crustal levels. (ii) Contrastingly rapid and discontinuous fluid flux and exfiltration is indicated by the presence of veins (e.g. quartz, epidote) and more importantly by the fluidized injections of ultrafine-grained gouge material 
eventually being initiated at sites of locally enhanced pore fluid pressures. Such fast processes are an efficient way to transport significant amounts of fluids through the highly localized fault zone channel.

\subsection{Frictional and viscous deformation and its cyclic behavior}

\subsubsection{Incipient brittle deformation as nucleus for strain localization}

Incipient brittle fracturing provoking subsequent dynamic recrystallization has been described in previous publications (e.g., van Daalen et al., 1999; Mancktelow, 2006; Vernooij et al., 2006; Fusseis and Handy, 2008; Diamond and Tarantola, 2015). In nature, recognition of these incipient precursor brittle structures is often difficult, since they usually vanish due to overprinting during ductile shear zone widening (Fig. 12). Low strain domains with limited ductile overprint (Fig. 12b see 3-6) therefore represent the most promising sites for the detection of brittle precursors on both the micro-scale (van Daalen et al., 1999; Vernooij et al., 2006; Diamond and Tarantola, 2015) as well as the m- to km-scale (e.g., Mancktelow and Pennacchioni, 2005; Fusseis et al., 2006). In the case of the shear zones of this study, several pieces of evidence reveal a brittle origin for many of the km-scale shear zones in the Aar massif: (i) straight and planar lateral appearance over kilometers, (ii) occurrence of biotite-coated fracture patterns on the millimeter to decameter scale as well as overprinting of brittle horse-tail structures by ductile shear zones at shear zone tips on the decameter scale (see also Wehrens et al., in review; their figure 5a-c). Besides the structural crosscutting/overprinting relation between incipient brittle and succeeding ductile structures, incipient fracturing is of great importance from a mechanical point of view, since a significant stress drop is expected between the stage of incipient non-localized to post-fracture deformation of the host rock (Fig. 13). Such early rate- and pressure-dependent fracturing therefore provides the base for subsequent ductilebrittle cycles acting with smaller stress variations (see below). A major new aspect of this study is the occurrence of the non-cohesive HT-cataclasites. In contrast to aforementioned HT-fractures with their biotite-coating, severe displacements in combination with fast energy releases are necessary to supply a considerable amount of non-cohesive polymineralic material as fluid-supported lubricant during strainrate weakening and the injection of the fluidized material into the off-fault fractures. Such events may have already occurred during the initialization stage but must be more prominent during succeeding stages of brittle-ductile cycles.

\subsubsection{Cyclical deformation behavior}

The change between frictional and viscous deformation at the FVT has often been discussed in earthquake geology (see introduction and Figs. 1, 12, 13 and 14). The role of rate dependency on deformation mechanisms and/or switches between different deformation mechanisms is incorporated in established FVT-models. Depending on the time-scale of interest, effective viscosity can be either expressed by a time-integrated approach (e.g., Noda and Shimamoto 2010; Shimamoto and Noda 2014 and references therein) or by the temporal resolution of the activity of different microstructural processes (e.g., Handy et 
al., 2007; Poulet et al., 2014). It is the latter time-scale, which actually links to switches in deformation processes resulting in changes from aseismic to seismic creep. Aforementioned structures and related deformation mechanisms demonstrate the alternating occurrences of mylonites dominated by viscousgranular-flow/dislocation creep and HT-fracturing. This can described as switching between frictional and viscous deformation (Figs. 13a). Transferred to crustal rheology such switches require modifications from the classical Christmas tree strength profiles (Fig. 1c, 13). In addition brittle and ductile end-member flow laws, cyclic behavior of brittle and ductile deformation as well as dominant deformation in ultrafinegrained polymineralic mylonites/cataclasites have to be integrated. The cyclic behavior is evident from two types of observations: (1) ductile overprinting relationships inside the HT-cataclasites and, vice versa, brittle overprinting in ultramylonites; as well as (2) the coexistence of repeated ductile and brittle deformation within the same pressure/temperature interval.

(1) The formation of microscopic epidote veins within the HT cataclasite matrix and their subsequent folding suggests that brittle and ductile deformation occur cyclically (Figs. 7c-d, 12 and 13). Prolonged periods of relatively slow viscous granular deformation are interrupted by events of rapid embrittlement. Folding of micro-scale epidote veins within the HT-cataclasite indicates the renewed onset of viscous granular flow after such fast brittle events (Fig. 8c, d). Also, the HT-ultramylonites contain former epidote veins, but additionally show highly elongated and deformed epidote-rich lenses indicating first an event of brittle vein formation followed by boudinage during subsequent viscous granular flow of the polymineralic ultramylonite (Figs. 9a, 12 and 14).

(2) Biotite-filled micro-fractures cutting through dynamically recrystallized quartz grains are one of the brittle structures overprinting ductile deformation (Fig. 7b-d). This requires primary viscous flow in quartz (mainly dislocation creep), which is overprinted by frictional processes at elevated biotitestable temperatures.

In summary, prolonged periods of slow viscous granular processes are interrupted by rapid brittle deformation. The positive feedback between localization and fluid-assisted chemical mass transfer (granular fluid pump) results in major strain softening (Figs. 1 and 13). Porosity destruction by mineral crystallization and fracture sealing, as seen for example by biotite overgrowths of the coupled grain coarsening of the matrix of the HT-cataclasite, induce a reduction in permeability. This reduction in permeability enables a recovery of the pore fluid pressure during stages of viscous flow, which results again in fracturing once the yield strength is reached. The subsequent post-fracturing stress- and pore fluid pressure drop causes again a switch, back into the viscous granular flow regime (Figs. 1, 12, 13 and 14). Under physical conditions of homogeneous flow (constant strain rate, constant mineral dissolution and precipitation, constant cavity formation) theoretically a steady state granular flow fabric may evolve. As shown in our deformation structures, however, microfabrics and deformation style are rather heterogeneous (see above). The simultaneous occurrence of synkinematic quartz-veins within ultramylonites suggests an interplay between the granular fluid pump (Etheridge et al. 1984, Fusseis et al., 2009) and a fault valve behavior in the sense of Sibson (1992). Combining the two models requires stages 
of slow but pervasive fluid flux in the fault zones during granular flow but also stages where locally pore fluid pressures enhance to induce hydrofracturing. The question by which processes and at which time scales the building up of elevated pore pressures occur in the granitoid crust (Figs. 13 and 14) and when the system starts to fail catastrophically in form of earthquake activity remains open and requires further research.

\subsection{Seismic versus aseismic behavior}

From surveillance of recent seismic activity in N-Switzerland it is known that earthquakes occur down to crustal depths of up to $20 \mathrm{~km}$ (e.g., Deichmann et al., 2000, 2011; Diehl et al. 2015), i.e. in a depth range structurally documented by the exhumed granitoid fault rocks of our study. In many studies, pseudotachylites are classically seen in such rocks as indicators for paleo-seismicity (Cowan, 1999; summary in Rowe \& Griffith 2015). Commonly, pseudotachylite formation is interpreted to occur under dry deformation conditions (Pennacchioni and Cesare, 1997; Yardley and Valley, 1997; Mancktelow and Pennacchioni, 2004) but evidence for pseudotachylite generation under hydrated conditions also exists (Magloughlin, 1992; Price et al. 2012). In the case of the hundreds of investigated shear zones of the Aar massif, we did not encounter any pseudotachylites. One may relate this paucity to the low preservation potential of these delicate deformation features (Sibson and Toy, 2006; Kirkpatrick et al., 2009; Kirkpatrick and Rowe, 2013). The lack of pseudotachylites in the Aar granitoids may either mean that (i) seismic strain rates were too slow to induce friction-induced melting, (ii) the friction between grains was not high enough to allow for significant temperature rises at the aggregate's scale, (iii) friction-induced heat was dissipated fast enough via advective fluid flow. The aforementioned recent seismic activity demonstrates that the studied granitoid rocks should have experienced episodes of fast seismic deformation during the exhumation history of the Aar massif and we therefore exclude (i). The presence of fluids strongly affects (ii) and (iii). In particular, the lubrication of grain boundaries by fluids, the fragmentation of rocks by seismic shaking at elevated pore fluid pressures and the advective heat transport during injection of the non-cohesive gouge into the host rock all counteract significant shearing inducedtemperature rises, which would be required for frictional melting. If true, a potential temperature rise by frictional heating during seismic faulting must therefore have been lower than the solvus of the wet granitoid crust. For these reasons, we speculate that the presence of fluids prevents pseudotachylite formation in the case of the granitoid rocks of the study area providing insights into alternative processes for energy dissipation during seismic events.

Particularly fluidization during embrittlement has been associated with seismicity in previous studies (Smith et al., 2008; Brodsky et al., 2009; Bjørnerud, 2010, Rowe \& Griffith 2015), where prolonged periods of slow viscous granular flow are interpreted to be interrupted by rapid seismic embrittlement. The observation of cyclic occurrences of frictional events, as shown in our study area, provides additional evidence for seismic activity (Scholz, 1998; Gratier et al., 2002; Handy and Brun 2004, Matysiak and 
561 Trepmann, 2012; Wintsch and Yeh, 2013). In this sense we conclude that the aforementioned HT562 cataclasite injection structures are indicators of paleo-seismic activity. Whereas the presence of substantial 563 amounts of fluids prevents the formation of pseudotachylites due to strain weakening and cooling effects, 564 representing an alternative explanation to shear melting as a focal mechanism of mid-crustal earthquakes.

565 In light of the preservation potential of such injection structures, best changes to find such remnants in 566 high strain zones are the low strain rims (left parts of Fig. 12) or domains within pressure shadows. In the 567 ductile high strain domains, however, ductile overprint of the short-term embrittlement structures will be severely overprinted if not even obliterated. This is particularly problematic in the case of isochemical compositions of host granite, injection structures and final mylonite. As demonstrated above, the injection structures often contain substantial amounts of epidote. We therefore suggest that the epidote-rich bands in Figures $9 \mathrm{a}$ and 12 represent older injections cycles, which experienced stages of high strain ductile overprint. Hence, the occurrence (distribution, spacing) of such epidote-rich bands within ultramylonites

\subsection{Linking the rock record to crustal-scale rheology profiles}

In this section, we link the observed microstructures and associated deformation mechanisms with potential crustal-scale rheology profile(s) incorporating their evolution in space and time. First, the simpler and well-explored monomineralic quartz system (e.g., Hirth et al. 2001, Hirth and Beeler 2015 and references therein) is treated before dealing with the more complex, but volumetrically far more dominant polymineralic granitoid system. We follow the considerations of Simamoto and Noda (2014) and link them with our field observations. Although few flow laws for viscous granular flow have been suggested (e.g. Paterson 1995, 2013, Platt 2015) their degree of uncertainty is still too high to satisfactorily describe the rheology of granitoid ultramylonites deformed in the range of $300-450^{\circ} \mathrm{C}$. We are therefore restricted at this stage to the conceptual level.

At elevated temperature and enhanced pore fluid pressure, i.e. at conditions with reduced effective pressure, both coarse-grained vein quartz and dynamically recrystallized quartz aggregates can

587 hydrofracture at seismic rates resulting in a drop in shear stress (steps $1 \& 2$ in Fig. 13a). Subsequent grain growth and dynamic recrystallization during the post-seismic deformation induces an adaptation of the now mylonitic microstructures to the slow interseismic deformation rates, first by strain hardening followed by steady-state or at least near steady-sate creep (step 3 in Fig. 13a). Simultaneously, the pore fluid pressure builds up again, before kicking off a renewed seismic event by ductile shear fracturing, where steps 2 and 3 repeat (Fig. 13a). Dilation accompanying the fracturing generates pore space enabling the precipitation of the biotite or the fine-grained polymineralic trails observed in Figure 7. Particularly the isometric quartz grains, with straight grain boundaries and $120^{\circ}$ triple junctions in the Aar massif microstructures closely resemble the experimental ones developed under coseismic conditions (Trepmann et al., 2007). 
597 In the case of the polymineralic granitoid host rock, similar initial hydrofracturing together with grain 598 refinement has to occur (either seismic or aseismic) in order to provide an incipient mechanical 599 discontinuity at both low and high temperatures (Fig. 13b, steps 4 and 6). For the entire range in 600 temperatures, this initial localization of deformation is fundamental for providing fine-grained 601 polymineralic aggregates controlling subsequent deformation by frictional granular flow and by cycles of 602 frictional/viscous granular flow at low and high temperatures, respectively (Figs 5, 8 and 9). In this way, a 603 first significant stress drop occurs (Fig. 13b, steps 4 and 6), ending with a polymineralic aggregate either 604 staying non-cohesive in the case of LT-interseismic creep or gaining strength owing to coupled-grain 605 coarsening at the HT-equivalent (Fig. 13b, steps 7 and 8), though the latter is limited in grain size increase 606 because of the typically slow coarsening kinetics in polymineralic aggregates (e.g., Herwegh et al., 2011 607 and references therein). In both cases, velocity strengthening will take place during interseismic slip but 608 owing to the fine-grained polymineralic aggregates, grain-size dependent granular flow guarantees shear 609 stresses much lower than those of the coarse-grained host rocks. Under the presence of fluids, build up of 610 pore fluid pressures will continue until the next seismic failure occurs (Fig. 13b steps 4 and 5 for LT as 611 well as of steps 9 and 8 for HT). In the case of high temperature deformation, thermal pore fluid 612 pressurization together with seismic shaking may help to generate instantaneous loss of intergranular 613 cohesion in the ultramylonties, allowing fast slip by velocity weakening as well as the injection of the now 614 non-cohesive polymineralic matrix into newly created off-fault fractures (Fig. 8b). In this way, the 615 generation of the fine-grained polymineralic matrices have three important consequences: (i) they reduce 616 the flow stresses during interseismic creep owing to grain-size-sensitive viscous granular flow rheology, 617 (ii) their deformation results in a build up of pore fluid pressure in cavities, which is necessary to induce a 618 new seismic event and last but not least (iii), once formed, they force strain to stay within the first order 619 mechanical discontinuities for the remaining deformation and exhumation history.

620 Note that besides rises in pore fluid pressures, the occurrence of brittle seismic events at dominantly 621 ductile crustal depths can also be explained by the friction to flow behavior (Shimamoto and Noda 2014) 622 or ductile shear fracturing (Weinberg and Regenauer-Lieb, 2009). We cannot rule out these processes but 623 our data clearly indicate the presence of fluids during seismic events in the area studied.

\section{Conclusions}

625 Under upper greenschist metamorphic conditions the investigated fault zones dominantly deform by ductile deformation, evidenced by the occurrence of quartz mylonites and, more importantly, by mylonites and ultramylonites with granitic composition. In addition to viscous granular flow, the presence of biotite628 coated fractures, cataclasites and injection structures of non-cohesive gouge material into weakly 629 deformed host rocks indicate periods of brittle deformation at temperatures up to $450^{\circ} \mathrm{C}$ and depths of 630 about $18-20 \mathrm{~km}$. Non-cohesive gouges must have been generated by fast deformation and considerable 631 energy releases at such HT-conditions but they are subsequently overprinted by ductile deformation 
resulting in repeated brittle-ductile cycles (see Figs. 12, 13 and 14). With progressive exhumation and cooling, deformation further localizes along these existing mechanical discontinuities and viscous granular flow becomes steadily replaced by cataclastic flow inside the fine-grained polymineralic fault rocks, where cycles of slow cataclastic flow and fast velocity weakening during elevated pore fluid pressures characterize the cycles of aseismic and seismic deformation.

In the past, the FVT in the Earth's crust has often been defined by means of a simplified quartz rheology at a depth interval of around 10-12 km (e.g., Fagereng and Toy, 2011). In the case of the granitoid crust (granites and gneisses) however, our study clearly indicates that quartz deformation plays a subordinate role and ultra-fine grained polymineralic fault rocks prevail the deformation structures encountered in the field. Hence at the crustal scale, they represent the most important rheology controlling material for which (under the presence of fluids) the lower limit of the FVT has to be expanded down to depths of up to $20 \mathrm{~km}$. The FVT is therefore not as sharp as suggested in previous studies. In this sense, our provided field evidence supports the concept of Shimamoto and Nuda (2014), suggesting a rather gradual transition between brittle and ductile flow over a considerable depth range. Despite the importance of major rock forming minerals in terms of crustal strength profiles (e.g., Ebert et al., 2008; Herwegh et al. 2011), recent studies increasingly point to the importance of an improved understanding of fine-grained polymineralic systems not only in the crust, but also in the upper mantle (e.g., Linckens et al. 2011, 2015). In this sense, the rheological evaluation of such polymineralic fault rocks is crucial in advancing understanding of deformation behavior at various crustal levels. In this light, future experiments on polymineralic granitoids are of great importance to improve our rheological understanding of deformation in the middle crust.

\section{Acknowledgements}

We thank Neil Mancktelow for fruitful discussions and field visits, and NAGRA for their support in our project. We are also grateful to J. Becker for an informal, and F. Fusseis and T. Shimamoto for official reviews. Financial support by SNF (project 20002-1132196) is greatly acknowledged. We thank Tom Belgrano for English corrections and discussions.

\section{References:}

Abrecht, J., 1994. Geologic units of the Aar massif and their pre-Alpine rock associations: a critical review: The preAlpine crustal evolution of the Aar-, Gotthard-and Tavetsch massifs. Schweiz. Mineral. Petrogr. Mitteil. 74, $5-27$.

Bambauer, H., Herwegh, M., Kroll, H., 2009. Quartz as indicator mineral in the Central Swiss Alps: the quartz recrystallization isograd in the rock series of the northern Aar massif. Swiss Journal of Geosciences 102, 345-351.

Barnhoorn, A., Bystricky, M., Kunze, K., Burlini, L., Burg, J.-P., 2005. Strain localisation in bimineralic rocks: experimental deformation of synthetic calcite-anhydrite aggregates. Earth and Planetary Science Letters $240,748-763$. 
Beeler, N.M., Hirth, G., Thomas, A, Bürgmann, R., 2016. Effective stress, friction, and deep crustal faulting. J. Geophys. Res. Solid Earth, 121, doi:10.1002/2015JB012115.

Belgrano, T.M., Herwegh, M., Berger, A.,, 2016Inherited structural controls on fault geometry, architecture and hydrothermal activity: an example from Grimsel Pass, Switzerland. Swiss Journal of Geosciences, published online DOI: 10.1007/s00015-016-0212-9

Bjørnerud, M., 2010. Rethinking conditions necessary for pseudotachylyte formation: Observations from the Otago schists, South Island, New Zealand. Tectonophysics 490, 69-80.

Blechschmidt I., Vomvoris S., 2010. Geological repository systems for safe disposal of spent nuclear fuels and radioactive waste, In: Underground research facilities and rock laboratories for the development of geological disposal concepts and repository systems: Ahn J.; Apted M.J. (eds.), Woodhead Publishing Series in Energy: Number 9, Woodhead Publishing Limited, Oxford, 82-118.

Bloomfield, J.P., Covey-Crump, S.J., 1993. Correlating mechanical data with micro- structural observations in deformation experiments on synthetic two-phase aggregates. Journal of Structural Geology 15, 1007-1019

Bos, B. and Spiers, C.J. 2001. Experimental investigation into the microstructural and mechanical evolution of phyllosilicate-bearing fault rock under conditions favouring pressure solution. Journal of Structural Geology 23, 1187-1202.

Boullier, A.-M. Yeh, E.-C.., Boutareaud, S., Song, S-R., Tsai, C.-H., 2009. Microscale anatomy of the 1999 Chi-Chi earthquake fault zone. Geochemistry, Geophysics, Geosystems, 10, Q03016. 10.1029/2008GC002252.

Brodsky, E.E., Rowe, C.D., Meneghini, F., Moore, J., 2009. A geological fingerprint of low - viscosity fault fluids mobilized during an earthquake. J. Geophys. Res. 114, 1978-2012.

Byerlee, J.D., 1978. Friction of rocks. Pure and Appl. Geophys. 116, 615-626.

Challandes, N., Marquer, D., Villa, I., 2008. P-T-t modelling, fluid circulation, and 39Ar- 40Ar and Rb-Sr mica ages in the Aar Massif shear zones (Swiss Alps). Swiss Journal of Geosciences 101, 269-288.

Christiansen, P.P., Pollard, D.D., 1997. Nucleation, growth and structural development of mylonitic shear zones in granitic rock. J. Struct. Geol. 19, 1159-1172.

Cowan, D.S., 1999. Do faults preserve a record of seismic slip? A field geologist's opinion. J. Struct. Geol. 21, 9951001 .

Cox, S., 2010. The application of failure mode diagrams for exploring the roles of fluid pressure and stress states in controlling styles of fracture-controlled permeability enhancement in faults and shear zones. Geofluids 10 , 217-233.

de Meer, S., Spiers, C.J., Peach, C.J., 1997. Pressure solution creep in gypsum: evidence for precipitation reaction control. Physics and Chemistry of the Earth 22,33-37.

Deer, W.A., Howie, R.A., Zussman, J., 1992. An introduction to the rock-forming minerals. Longman Scientific \& Technical Hong Kong.

Deichmann, N., Dolfin, D.B., Kastrup, U., 2000. Seismizität der Nord-und Zentralschweiz: Dezember 2000. Nagra.

Deichmann, N., Sellami, S., Giradini, D. 2011. La Suisse tremble Sismotectonique des Alpes et du Plateau Suisse. Géochronique 117, 57-60.

Diamond, L., Tarantola, A., 2015. Interpretation of fluid inclusions in quartz deformed by weak ductile shearing: Reconstruction of differential stress magnitudes and pre-deformation fluid properties. Earth Planet. Sci. Lett. 417, 107-119. 
Diehl, T., Deichmann, N., Clinton, J., Kästli, P., Cauzzi, C., Kraft, T., Behr, Y., Edwards, B., Guilhem, A., Korger, E., Hobiger, M., Haslinger, F., Fäh, D., Wiemer, S., 2015. Earthquakes in Switzerland and surrounding regions during 2014. Swiss Journal of Geosciences 108, 425-443.

Duretz, T., Schmalholz, S.M., Podladchikov, Y.Y., 2015. Shear heating-induced strain localization across the scales. Philosophical Magazine 95, 3192-3207.

Ebert, A., Herwegh, M., Pfiffner, A., 2007. Cooling induced strain localization in carbonate mylonites within a largescale shear zone (Glarus thrust, Switzerland). J. Struct. Geol. 29, 1164-1184.

Etheridge, M.A., Wall, V., Cox, S., Vernon, R., 1984. High fluid pressures during regional metamorphism and deformation: implications for mass transport and deformation mechanisms. J. Geophys. Res. (1978-2012) $89,4344-4358$.

Fagereng, A. Toy, V.G., 2011, Geology of the earthquake source: an introduction. Fagereng, A., Toy, V. G. \& Rowland, J. V. (eds) Geology of the Earthquake Source: A Volume in Honour of Rick Sibson. Geological Society, London, Special Publications, 359, 1-16.

Fitz Gerald, J., Stünitz, H., 1993. Deformation of granitoids at low metamorphic grade. I: reactions and grain size reduction. Tectonophysics 221, 269-297.

Fliervoet, T.F., White, S.H., Drury, M.R., 1997. Evidence for dominant grain-boundary sliding deformation in greenschist- and amphibolite-grade polymineralic ultramylonites from the Redbank Deformed Zone, Central Australia. J. Struct. Geol. 19, 1495-1520.

Fondriest, M., Smith, S.A.F., Candela, T., Nielsen, S.B., Mair, K., Di Toro, G., 2013. Mirror-like faults and power dissipation during earthquakes. Geology 41 (11), 1175-1178.

Fossen, H., 2010. Structural geology. Cambridge University Press.

Fusseis, F., Handy, M., 2008. Micromechanisms of shear zone propagation at the brittle-viscous transition. J. Struct. Geol. 30, 1242-1253.

Fusseis, F., Handy, M.R., Schrank, C., 2006. Networking of shear zones at the brittle-to-viscous transition (Cap de Creus, NE Spain). J. Struct. Geol. 28, 1228-1243.

Fusseis, F., Regenauer-Lieb, K., Liu, J., Hough, R.M., De Carlo, F., 2009. Creep cavitation can establish a dynamic granular fluid pump in ductile shear zones. Nature 459, 974-977.

Gerya, T., 2010. Introduction to Numerical Geodynamic Modelling. Cambridge University Press.

Goetze, C. and Evans, B., 1978. Stress and temperature in the bending lithosphere as constrained by experimental rock mechanics. Geophysical Journal International 59 (3), 463-478

Goncalves, P., Oliot, E., Marquer, D., Connolly, J.A.D., 2012. Role of chemical processes on shear zone formation: an example from the Grimsel metagranodiorite (Aar massif, Central Alps). J. Metam. Geology 30, 703-722.

Gratier, J.-P., Favreau, P., Renard, F., Pili, E., 2002. Fluid pressure evolution during the earthquake cycle controlled by fluid flow and pressure solution crack sealing. Earth Planets and Space 54, 1139-1146.

Guermani, A., Pennacchioni, G., 1998. Brittle precursors of plastic deformation in a granite: an example from the Mont Blanc massif (Helvetic, western Alps). J. Struct. Geol. 20, 135-148.

Handy, M.R., 1989. Deformation regimes and the rheological evolution of fault zones in the lithosphere: the effects of pressure, temperature, grainsize and time. Tectonophysics 163, 119-152.

Handy, M.R., Brun, J.-P., 2004. Seismicity, structure and strength of the continental lithosphere. Earth Planet. Sci. Lett. 223, 427- 441 
Handy, M.R., Hirth, G., Brügmann, R., 2007. Continental Fault Structure and Rheology from the Frictional-toViscous Transition Downward. In Tectonic Faults: Agents of Change on a Dynamic Earth, ed. MR Handy, G Hirth, N Hovius, pp. 139-81. Cambridge, MA: MIT

Herwegh, M. and Handy, M.R., 1996. The Evolution of High Temperature Mylonitic Microfabrics: Evidence from Simple Shearing of a Quartz Analogue (Norcamphor). J. Struct. Geol. 18, 689-710.

Herwegh, M., Jenni, A., 2001. Granular flow in polymineralic rocks bearing sheet silicates: new evidence from natural examples. Tectonophysics 332, 309-320.

Herwegh, M., Kunze, K., 2002. The influence of nano-scale second-phase particles on deformation of fine grained calcite mylonites. J. Struct. Geol. 24, 1463-1478.

Herwegh, M., Linckens, J., Ebert, A., Berger, A., Brodhag, S., 2011, The role of second phases for controlling microstructural evlution in polymineralic rocks: A review. J. Struct. Geol. 33, 1728-1750.

Hirth, G., Teyssier, C. \& Dunlap, W. 2001. An evaluation of quartzite flow laws based on comparisons between experimentally and naturally deformed rocks. International Journal of Earth Sciences, 90, 77-87.

Hirth, G. and Beeler, N.M., 2015, The role of fluid pressure on frictional behavior at the base of the seismogenic zone. Geology, 43, 223-226.

Hirth, G., Tullis, J., 1992 Dislocation creep regimes in quartz aggregates, J. Struct. Geol., 14, 145-159,

Işık, V., Seyitoğlu, G., Çemen, İ., 2003. Ductile-brittle transition along the Alaşehir detachment fault and its structural relationship with the Simav detachment fault, Menderes massif, western Turkey. Tectonophysics $374,1-18$.

Kawamoto, E., Shimamoto, T., 1998: The strength profile for bimineralic shear zones: an insight from hightemperature shearing experiments on calcite-halite mixtures. Tectonophysics $295,1-14$

Keulen, N., Heilbronner, R., Stünitz, H., Boullier, A-M., Ito, H., (2007), Grain size distributions of fault rocks: A comparison between experimentally and naturally deformed granitoids. J. Struct. Geol. 29, 1282-1300.

Keusen, H.R., Ganguin, J., Schuler, P., Buletti, M., 1989. Grimsel test site - Geology, Nagra technical report NTB 87-14E, Nagra, Wettingen, Switzerland, Nagra technical report. NAGRA.

Kilian, R., Heilbronner, R., Stünitz, H., 2011. Quartz grain size reduction in a granitoid rock and the transition from dislocation to diffusion creep. J. Struct. Geol. 33, 1265-1284.

Kirkpatrick, J.D., Rowe, C.D., 2013. Disappearing ink: how pseudotachylytes are lost from the rock record. J. Struct. Geol. 52, 183-198.

Kirkpatrick, J.D., Shipton, Z.K., Persano, C., 2009. Pseudotachylytes: rarely generated, rarely preserved or rarely reported? Bull. Seismol. Soc. Am. 99, 382e388. http://dx.doi.org/10.1785/0120080114.

Kohlstedt, D.L., Evans, B., Mackwell, S. J., 1995. Strength of the lithosphere: Constraints imposed by laboratory experiments. J. Geophys. Res. 100, B9, 17587-17602.

Kruse, R., Stünitz, H., 1999. Deformation mechanisms and phase distribution in mafic high temperature mylonites from the Jotun Complex, Norway. Tectonophysics, 303, 223-251.

Linckens, J., Herwegh, M., Müntener, O., 2015. Small quantity but large effect - How minor phases control strain localization in upper mantle shear zones. Tectonophysics, 643, 26-43.

Linckens, J., Herwegh, M., Müntener, O., Mercolli, I., 2011. Evolution of a polymineralic mantle shear zone and the role of second phases in the localization of deformation. J. Geophys. Res. 116, B06210. 
Magloughlin, J.F., 1992. Microstructural and chemical changes associated with cataclasis and frictional melting at shallow crustal levels: the cataclasite-pseudotachylyte connection. Tectonophysics 204, 243-260.

Mancktelow, N.S. 2006. How ductile are ductile shear zones? Geology, 34, 345-348.

Mancktelow, N.S., Pennacchioni, G., 2004. The influence of grain boundary fluids on the microstructure of quartzfeldspar mylonites. J. Struct. Geol. 26, 47-69.

Mancktelow, N.S., Pennacchioni, G., 2005. The control of precursor brittle fracture and fluid-rock interaction on the development of single and paired ductile shear zones. J. Struct. Geol. 27, 645-661.

Mancktelow, N.S., Pennacchioni, G., 2013, Late magmatic healed fractures in granitoids and their influence on subsequent solid-state deformation. J. Struct. Geol. 57, 81-96.

Marone, C., 1998. Laboratory-derived friction laws and their application to seismic faulting. Annu. Rev. Earth Planet. Sci. 26, 643-696.

Marquer, D., Gapais, D., Capdevila, R., 1985. Comportement chimique et orthogneissification d'une granodiorite en facies schistes verts (Massif de l'Aar, Alpes Centrales). Bulletin de minéralogie 108, 209-221.

Marsh, J.H., Johnson, S.E., Yates, M.G. , West, D.P., 2009. Coupling of deformation and reactions during midcrustal shear zone development: an in situ frictional-viscous transition. Journal of Metamorphic Geology, $27,531-553$.

Matysiak, A.K., Trepmann, C.A., 2012. Crystal-plastic deformation and recrystallization of peridotite controlled by the seismic cycle. Tectonophysics 530, 111-127.

Menegon, L., Fusseis, F., Stunitz, H., Xiao, X., 2015. Creep cavitation bands control porosity and fluid flow in lower crustal shear zones. Geology, 43, 227-230.

Menegon, L., Stunitz, H., Nasipuri, P., Heilbronner, R., Svahnberg, H., 2013. Transition from fracturing to viscous flow in granulite facies perthitic feldspar (Lofoten, Norway). J. Struct. Geol. 48, 95-112.

Monzawa, N., Otsuki, K., 2003. Comminution and fluidization of granular fault materials: implications for fault slip behavior. Tectonophysics 367, 127-143.

Niggli, C.R., 1965. Petrographie und Petrogenesis der Migmatite und Gneise im südlichen Aarmassiv zwischen Obergesteln und Furkapass, PhD Thesis, University of Bern.

Noda, H., Shimamoto, T., 2010. A rate- and state-dependent ductile flow law of polycrystalline halite under large shear strain and implication for transition to brittle deformation, Geophys. Res. Lett., 37, L09310, doi:10.1029/2010GL042512.

Nylese, T., Anderhalt, R., 2014. Advanced Materials Characterization with Full-Spectrum Phase Mapping. Microscopy Today 22, 18-23.

Otsuki, K., Monzawa, N., Nagase, T., 2003. Fluidization and melting of fault gouge during seismic slip: Identification in the Nojima fault zone and implications for focal earthquake mechanisms. J. Geophys. Res. 108 (B42192), 18. http:// dx.doi.org/10.1029/2001JB001711.

Paterson, M.S., 1995. A theory for granular flow accommodated by material transfer via an intergranular fluid. Tectonophysics $245,135-151$.

Paterson, M.S., 2013. Materials science for structural geology. Springer, Doordrecht

Pennacchioni, G. Di Toro, G., Brack, P., Menegon, L., Villa, I.M., 2006, Brittle-ductile-brittle deformation during cooling of tonalite (Adamello, Southern Italian Alps), Tectonophysics, 427, 171-197 
Pennacchioni, G., 2005. Control of the geometry of precursor brittle structures on the type of ductile shear zone in the Adamello tonalites, Southern Alps (Italy). J. Struct. Geol. 27, 627-644.

Pennacchioni, G., Cesare, B., 1997. Ductile - brittle transition in pre - Alpine amphibolite facies mylonites during evolution from water - present to water - deficient conditions (Mont Mary nappe, Italian Western Alps). Journal of Metamorphic Geology 15, 777-791.

Pennacchioni, G., Mancktelow, N.S., 2007. Nucleation and initial growth of a shear zone network within compositionally and structurally heterogeneous granitoids under amphibolite facies conditions. J. Struct. Geol. 29, 1757-1780.

Platt, J.P. and Behr, W.M., 2011. Lithospheric shear zones as constant stress experiments. Geology, 39, $127-130$.

Platt, J.P., 2015. Rheology of two-phase systems: A microphysical and observational approach. J. Struct. Geol. 77, 213-227

Price, N.A., Johnson, S.E., Gerbi, C.C., West, D.P., 2012. Identifying deformed pseudotachylyte and its influence on the strength and evolution of a crustal shear zone at the base of the seismogenic zone. Tectonophysics 518$521,63-83$.

Ranalli, G., 1995. Rheology of the Earth, Deformation and Flow Processes in Geo-physics and Geodynamics. Chapman \& Hall.

Ree, J.-H., 1991. High Temperature Deformation of Octachloropropane: A Microstructural Study, University at Albany, State University of New York, Department of Geological Sciences.

Regenauer-Lieb, K. and Yuen, D.A. 2004. Positive feedback of interacting ductile faults from coupling of equation of state, rheology and thermal-mechanics, Physics of the Earth and Planetary Interiors,142, 113-135.

Regenauer-Lieb, K., Hobbs, B., Ord, A., Gaede, O., Vernon, R., 2009. Deformation with coupled chemical diffusion. Physics of the Earth and Planetary Interiors 172, 43-54

Regenauer-Lieb, K., Yuen, D.A., 2003. Modeling shear zones in geological and planetary sciences: solid- and fluidthermal-mechanical approaches. Earth- Science Reviews 63 (3-4), 295-349.

Rolland, Y., Cox, S.F., Corsini, M., 2009. Constraining deformation stages in brittle-ductile shear zones from combined field mapping and 40Ar/39Ar dating: The structural evolution of the Grimsel Pass area (Aar Massif, Swiss Alps). J. Struct. Geol. 31, 1377-1394.

Rossi, M. Rolland, Y., Vidal, O., Cox, S. F., 2005. Geochemical variations and element transfer during shearzonedevelopment and related episyenites at middle crust depths: insights from the Mont Blanc granite (French-Italian Alps). In Bruhn, D. \& Burlini, L. (eds) 2005. High-Strain Zones." Structure and Physical Properties. Geological Society, London, Special Publications, 245, 373-396.

Rowe, C.D., Griffith, W.A., 2015, Do faults preserve a record of seismic slip: A second opinion. J. Struct. Geol. 78, $1-26$

Rowe, C.D., Kirkpatrick, J.D., Brodsky, E.E., 2012. Fault rock injections record paleoearthquakes. Earth Planet. Sci. Lett. 335-336, 154-166.

Rutter, E.H., 1983. Pressure solution in nature, theory and experiment. J. Geol. Soc. London, 140, 725-740.

Rutter, E.H., 1986. On the nomenclature of mode of failure transitions in rocks. Tectonophysics 122 (3-4), 381-387.

Schaltegger, U., 1990. Post-magmatic resetting of Rb-Sr whole rock ages - a study in the Central Aar Granite (Central Alps, Switzerland). Geol. Rundsch. 79, 709-724. 
Schaltegger, U., 1994. Unravelling the pre-Mesozoic history of Aar and Gotthard massifs (Central Alps) by isotopic dating: a review : The pre-Alpine crustal evolution of the Aar-, Gotthard- and Tavetsch massifs. Schweizerische mineralogische und petrographische Mitteilungen 74, 41-51.

Schmid, S., Casey, M., 1986. Complete fabric analysis of some commonly observed quartz c - axis patterns. Mineral and Rock Deformation: Laboratory Studies: The Paterson Volume, 263-286.

Schmid, S., Handy, M., 1991. Towards a genetic classification of fault rocks: Geological usage and tectonophysical implications. In: Controversies in Modern Geology (DW Müller, JA McKenzie \& H. Weissert, editors), Academic Press London, 339-361.

Scholz, C.H., 1998. Earthquakes and friction laws. Nature 391, 37-42.

Segall, P., Simpson, C., 1986. Nucleation of ductile shear zones on dilatant fractures. Geology 14, 56-59.

Shimamoto and Noda 2014. A friction to flow constitutive law and its application to a 2-D modeling of earthquakes. J. Geophys. Res. Solid Earth, 119, 8089-8106, doi:10.1002/2014JB011170.

Shimamoto, T., 1986. Transition between frictional slip and ductile flow for halite shear zones at room temperature, Science, 231, 711-714.

Sibson, R. H. 2011. The scope of earthquake geology. In: Fagereng, A ., Toy, V. G. \& Rowland, J. V. (eds) Geology of the Earthquake Source: A Volume in Honour of Rick Sibson. Geological Society, London, Special Publications, 359, 319-332.

Sibson, R., 1977. Fault rocks and fault mechanisms. Journal of the Geological Society 133, 191-213.

Sibson, R., 1980. Transient discontinuities in ductile shear zones. J. Struct. Geol. 2, 165-171.

Sibson, R., 1992. Implications of fault-valve behaviour for rupture nucleation and recurrence. Tectonophysics 211, 283-293.

Sibson, R.H., 1981. Fluid flow accompanying faulting: field evidence and models. Earthquake prediction, 593-603.

Sibson, R.H., 1989. Earthquake faulting as a structural process. J. Struct. Geol. 11, 1-14.

Sibson, R.H., Toy, V.G., 2006. The habitat of fault-generated pseudotachylyte: presence vs. absence of friction-melt. In: Abercrombie, R., McGarr, A., Kanamori, H., Di Toro, G. (Eds.), Earthquakes: Radiated Energy and the Physics of Faulting, Geophysical Monograph 170. American Geophysical Union, 153-166.

Smith, S., Collettini, C., Holdsworth, R., 2008. Recognizing the seismic cycle along ancient faults: CO2-induced fluidization of breccias in the footwall of a sealing low-angle normal fault. J. Struct. Geol. 30, 1034-1046.

Snoke, A.W., Tullis, J., Todd, V.R. (1998) Fault-related Rocks:A Photographic Atlas 634pp. Princeton University Press

Stalder, H.A., 1964. Petrographische und mineralogische Untersuchungen im Grimselgebiet (mittleres Aarmassiv), PhD Thesis, University of Bern.

Steck, A., 1968. Die alpidischen Strukturen in den Zentralen Aaregraniten des westlichen Aarmassivs. Eclogae Geologicae Helvetiae 61, 19-48.

Stipp, M., Stünitz, H., Heilbronner, R., Schmid, S.M., 2002. The eastern Tonale fault zone: a 'natural laboratory' for crystal plastic deformation of quartz over a temperature range from 250 to 700 C. J. Struct. Geol. 24, 18611884.

Stünitz, H., 1993. Transition from fracturing to viscous flow in a naturally deformed metagabbro. Defects and Processes in the Solid State: Geoscience Applications, 121-150. 
Stünitz, H., 1998. Syndeformational recrystallization-dynamic or compositionally induced? Contributions to Mineralogy and Petrology 131, 219-236.

Stünitz, H., Fitzgerald, 1993. Deformation of granitoids at low metamorphic grade .2. granular flow in albite-rich mylonites. Tectonophysics 221, 299-324.

Stünitz, H., Tullis, J., 2001. Weakening and strain localization produced by syn-deformational reaction of plagioclase. International Journal of Earth Sciences, 90, 136-148.

Tanaka, Y., Miyakawa, K., Fukahori, D., Kiho, K., Goto, K. 2014. Survey of Flow Channels in Rock Mass Fractures by Resin Injection. Proceedings 8th Asian Rock Mechanics Symposium, ARMS8, 14-16 October 2014, Sapporo, Japan

Trepmann, C.A., Stöckhert, B., Dorner, D., Moghadam, R., Küster, M., Röller, K., 2007. Simulating coseismic deformation of quartz in the middle crust and fabric evolution during postseismic stress relaxation - An experimental study, Tectonophysics, 442, 83-104. DOI: 10.1016/j.tecto.2007.05.005.

van Daalen, M., Heilbronner, R., Kunze, K., 1999. Orientation analysis of localized shear deformation in quartz fibres at the brittle-ductile transition. Tectonophysics 303, 83-107.

van der Elst, N., Brodsky, E.E., Le Bas, P.Y., Johnson, P.A., 2012. Auto-acoustic compaction in steady shear flows: experimental evidence for suppression of shear dilatancy by internal acoustic vibration. J. Geophys. Res. 117, B9.

Vernooij, M., Kunze, K., den Brok, B., 2006. 'Brittle' shear zones in experimentally deformed quartz single crystals. J. Struct. Geol. 28, 1292-1306.

Watts, L.M., Holdsworth, R.E., Sleight, J.A., Strachan, R.A., Smith, S.A.F., 2007. The movement history and fault rock evolution of a reactivated crustal-scale strike-slip fault: the Walls Boundary Fault Zone, Shetland. Journal of the Geological Society 164, 1037-1058.

Wehrens, P. 2015. Structural evolution in the Aar Massif (Haslital transect): Implications for mid-crustal deformation. PhD thesis University Bern

Wehrens, P., Baumberger, R., Berger, A., Herwegh, M., in review. How is strain localized in a mid-crustal basement section? Spatial distribution of deformation in the Aar massif (Switzerland). J. Struct. Geol.

Weinberg, R., Regenauer-Lieb, K., 2009, Ductile fractures and magma migration from source. Geology 38, 363-366.

Wintsch, R.P., Yeh, M.-W., 2013. Oscillating brittle and viscous behavior through the earthquake cycle in the Red River Shear Zone: Monitoring flips between reaction and textural softening and hardening. Tectonophysics 587, 46-62.

Yardley, B.W., Valley, J.W., 1997. The petrologic case for a dry lower crust. J. Geophys. Res. 102, 12173-12185. 


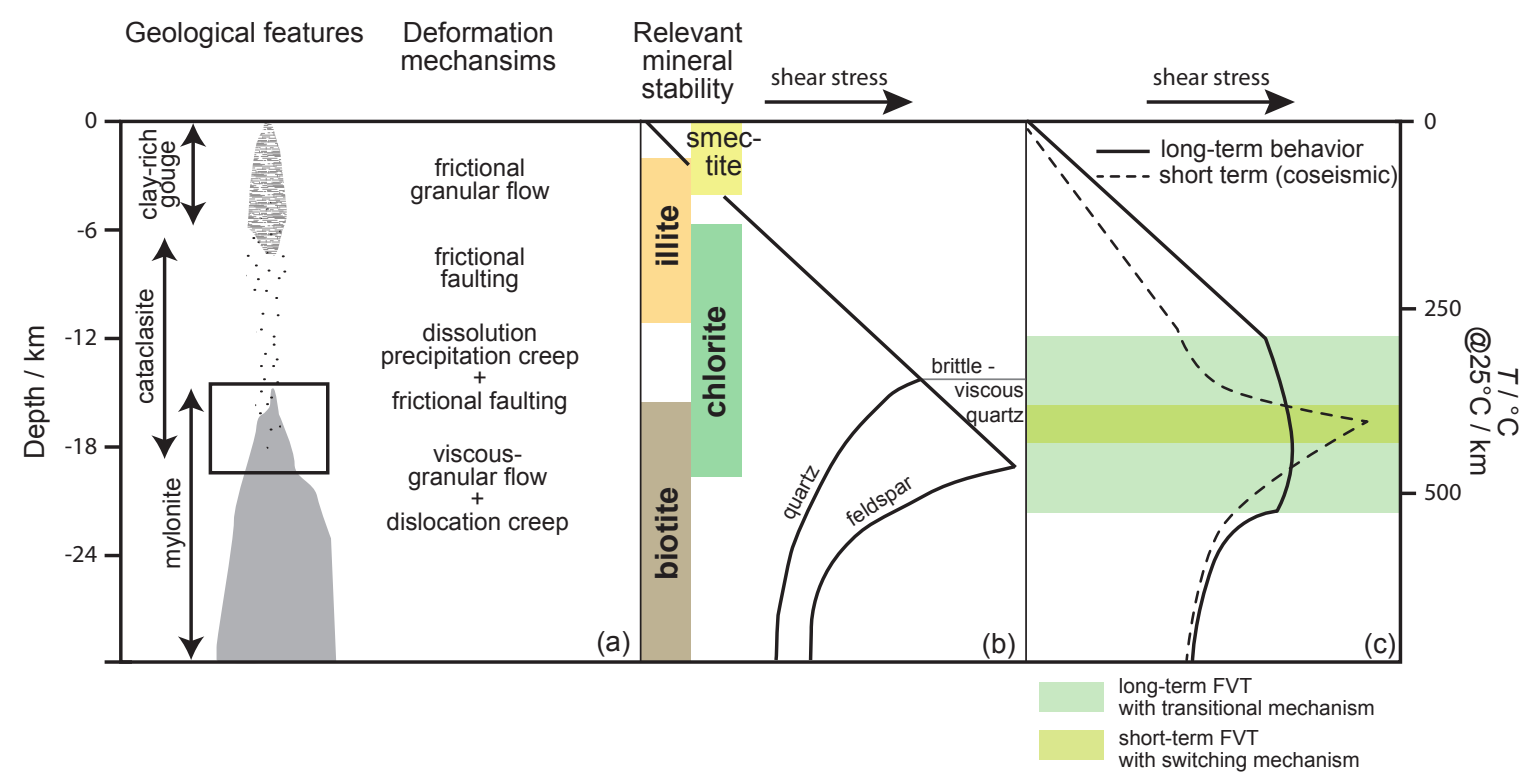

Fig. 1: (a) Conceptual fault-zone model (see Fagereng and Toy, 2011 and reference therein); (b) Schematic crustal strength profiles which are based on experimental data of monomineralic rocks (i.e. quartz and feldspar); (c) Schematic crustal strength profiles for different time intervals. The long-term behavior averages over time intervals of $10^{3}-10^{5}$ years (Handy et al. 2007) . 


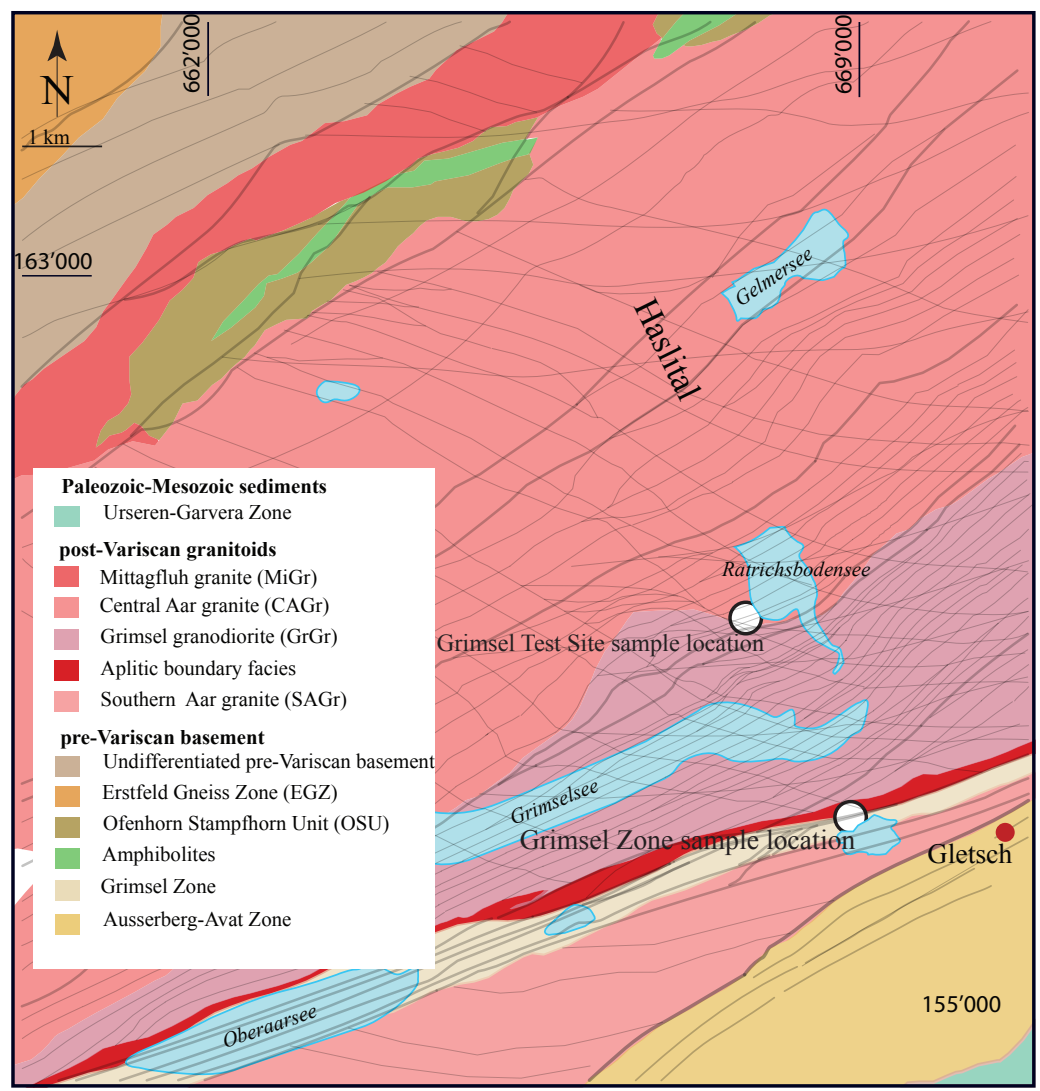

Fig. 2: Geological map of the upper Haslital area with ductile shear zones (grey lines) that show a width larger than $10 \mathrm{~cm}$. Indicated are the two sample locations mentioned specifically in the text. 

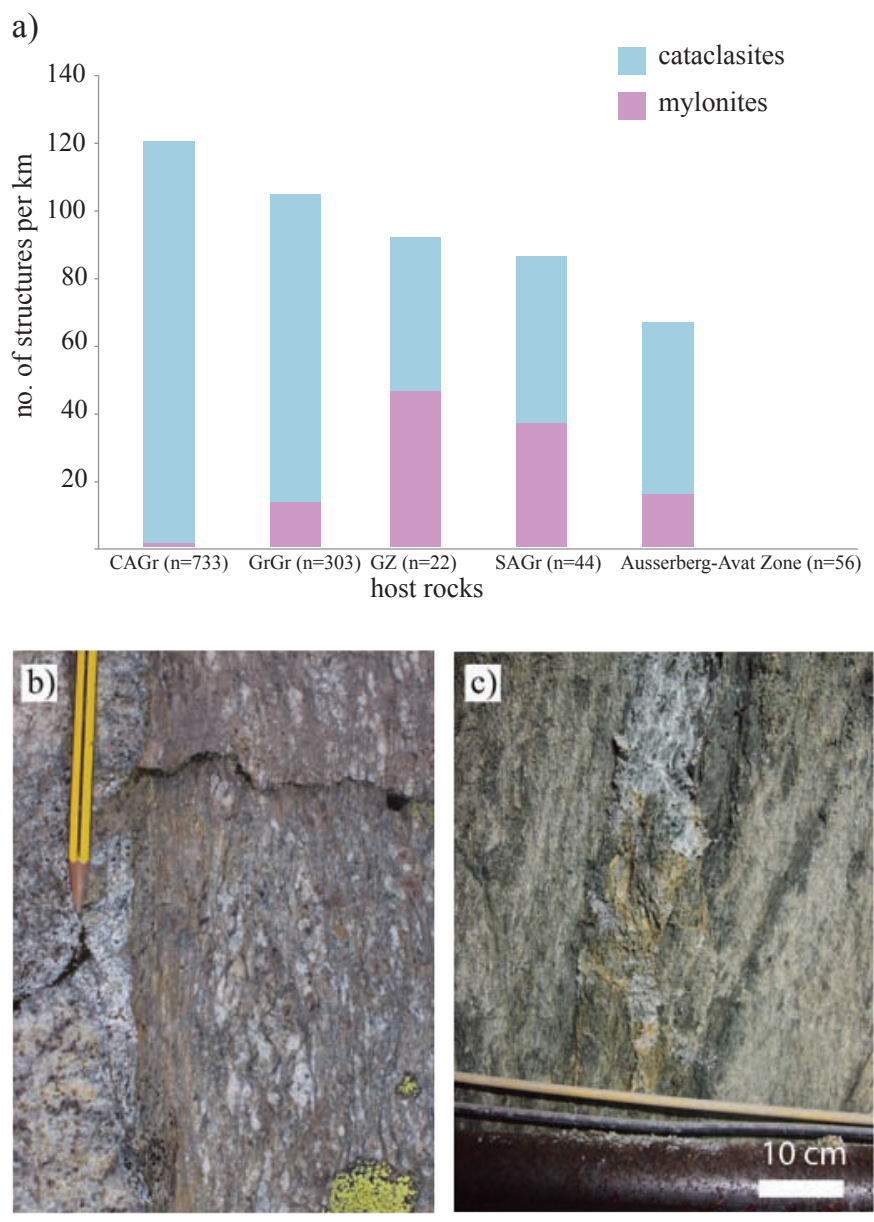

Fig. 3: (a) Graph showing changes in deformation density for each lithological unit, indicated as number of both cataclasites and mylonites per $\mathrm{km}$. Note that the width of cataclasites is mostly restricted to few $\mathrm{mm}$ to $\mathrm{cm}$, whereas mylonites may have widths up to several meters. CAGR: Central Aar granite, GrGr: Grimsel granodiorite, GZ: Grimsel Zone, SWAGR: Southwestern Aar granite. (b) Outcrop photo of a small ductile shear zone in the CAGr. An asymmetric strain gradient is manifest by a transition from schistose (left part of photo) to ultramylonitic fabric (central part of photo) and the contact to weakly deformed rock (left). (c) Subsurface outcrop photo of a brittle fault zone characterized by a fault gouge. 

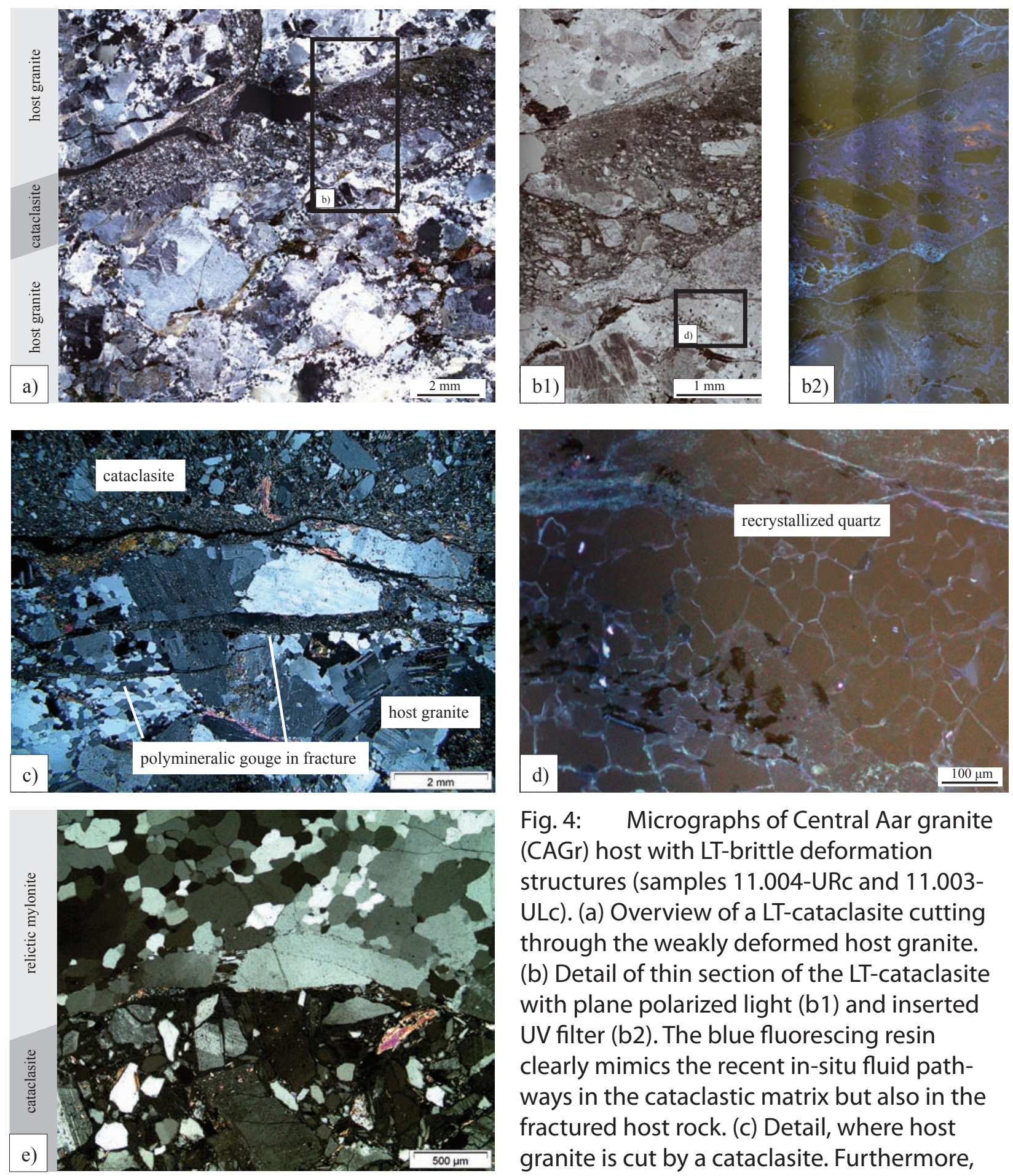

Fig. 4: $\quad$ Micrographs of Central Aar granite (CAGr) host with LT-brittle deformation structures (samples 11.004-URc and 11.003ULC). (a) Overview of a LT-cataclasite cutting through the weakly deformed host granite. (b) Detail of thin section of the LT-cataclasite with plane polarized light (b1) and inserted UV filter (b2). The blue fluorescing resin clearly mimics the recent in-situ fluid pathways in the cataclastic matrix but also in the fractured host rock. (c) Detail, where host granite is cut by a cataclasite. Furthermore, secondary fractures, filled with a fine-grained polymineralic gouge merge out of the cataclasite and cut into the host rock. (d) Dynamically recrystallized quartz aggregate with grain boundaries that are filled with UV fluorescent resin indicate in-situ fluid permeability at the grain boundary scale within the host rock. (e) low temperature fracturing overprinting viscuous mylonites. Note the parallel overprinting. 


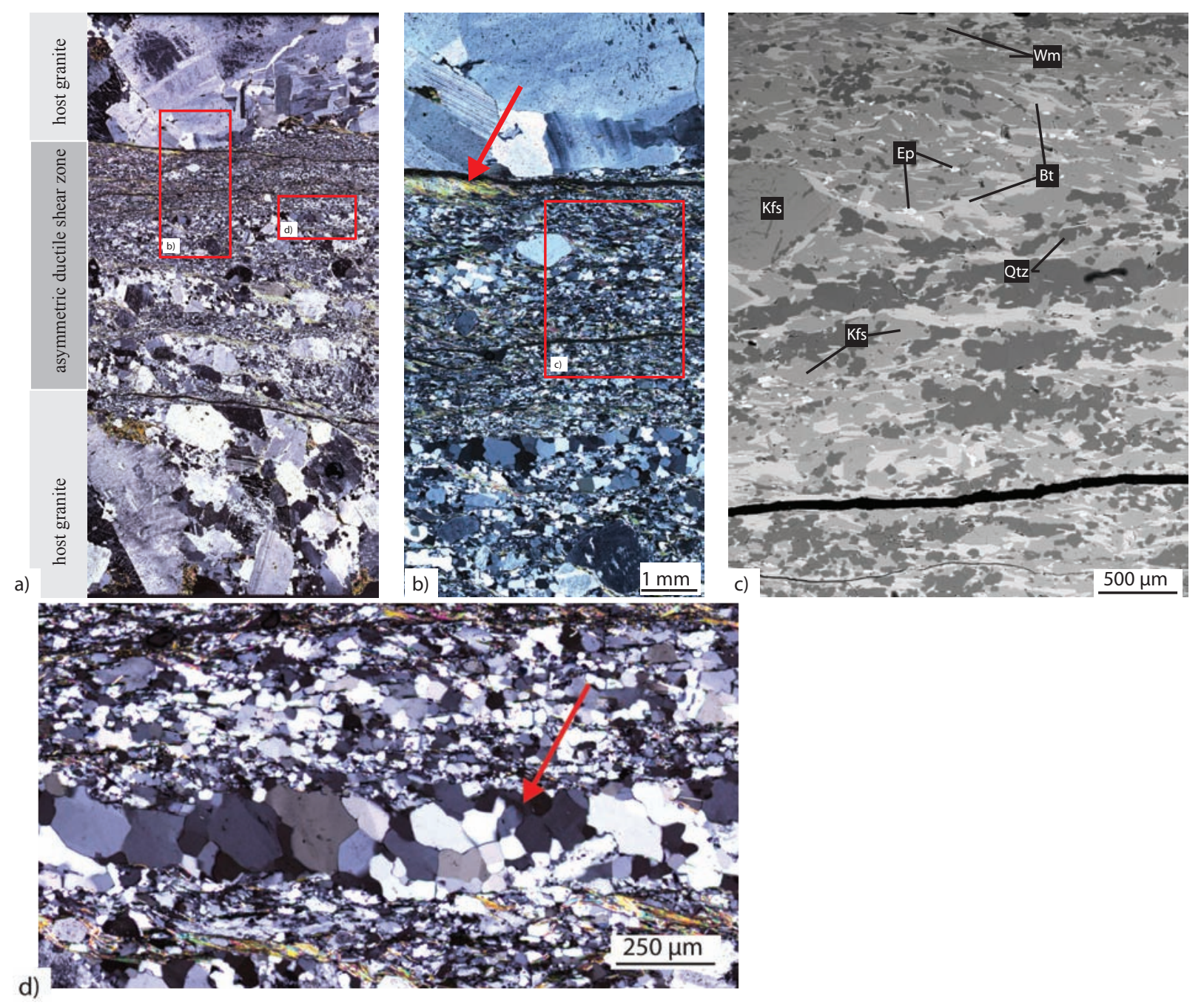

Fig. 5: Micrographs of a ductile shear zone, which dissects the weakly deformed Central Aar granite. (a) Overview of the asymmetric strain gradient from host rock (bottom of image) to a schistose and a mylonitic fabric with a sharp contact to the host (top of image). (b) Detail of the deformation fabric of (a). Clearly visible are elongated polycrystalline quartz domains and a very fine-grained polymineralic matrix as well as a white mica band (indicated with the red arrow). (c) Backscatter electron image of the polymineralic matrix and a feldspar clast. (d) Detail of a monomineralic recrystallized quartz domain (indicated with the red arrow). 

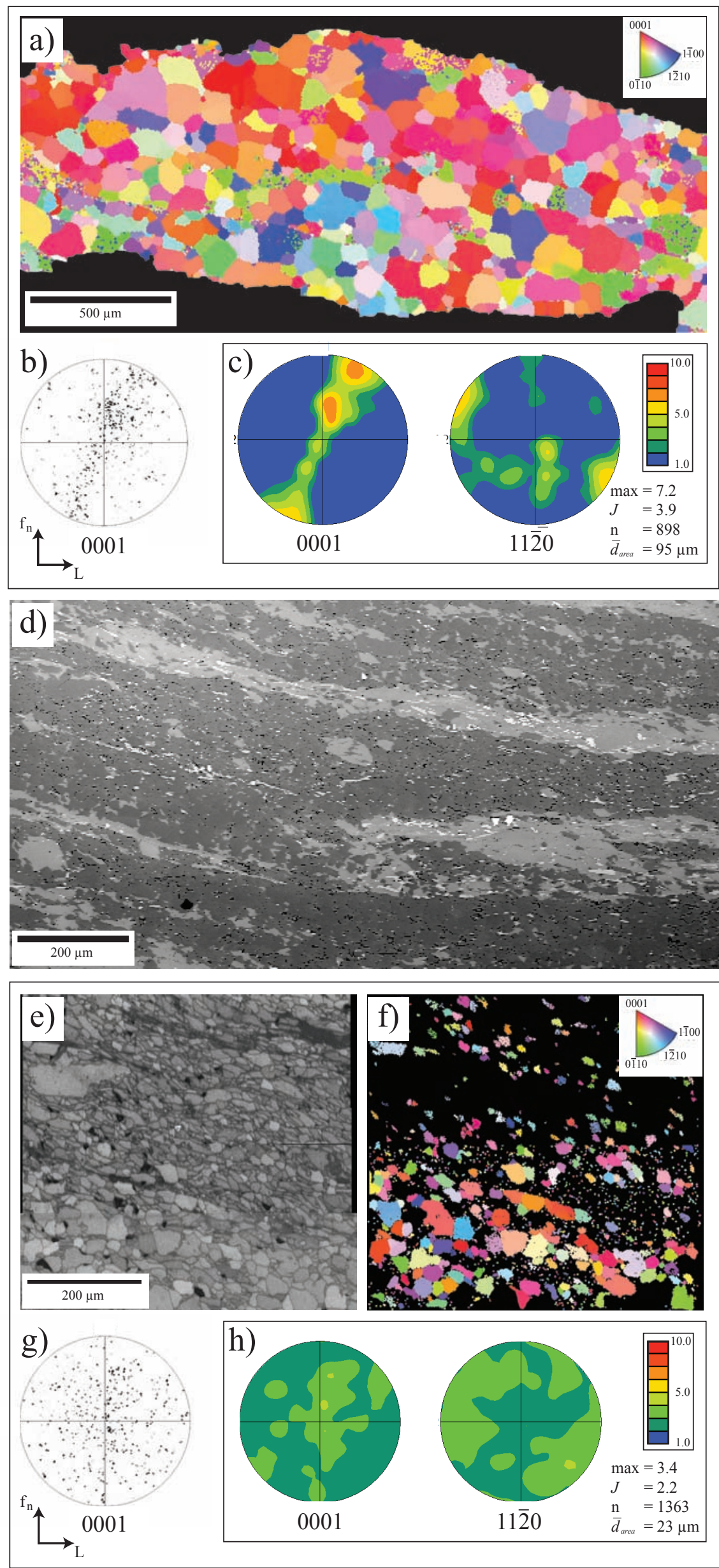

Fig. 6: Detailed study of the characteristic microstructures and textures of (a)-(c) a completely dynamically recrystallized monomineralic quartz domain and (d)-(h) of polymineralic layers deformed by viscous granular flow (Sample Gr10). (a) Grain orientation map (inverse pole figure map) obtained from EBSD measurements, (b) related pole figure diagrams with [c]-axis raw data; (d) contoured [c]- and <a> axis data (lower hemisphere, equal-area, linear contouring) of a dynamically recrystallized pure quartz aggregate undergoing dislocation creep. (d) BSE image showing mica-rich bands (bright grey) with fine-grained polymineralic layers. (e) Image quality map and $(\mathrm{f})$ grain orientation map of finely dispersed quartz in a polymineralic aggregate (compare $(\mathrm{e})$ and $(\mathrm{f})$ ). Stereographic pole figures with $(\mathrm{g})$ [c]-axis raw data and (h) contoured [c]- and <a> axis data. Note the smaller quartz grain sizes and the absence of a crystallographic preferred orientation in case of (a),(h) compared to (f),(c). Step size: $5 \mu \mathrm{m}$. Mean = area-weighted mean grain size; $n=$ number of measurements, max $=$ maximum intensity of $[c]$ pole figure. $L=$ stretching lineation; fn $=$ foliation normal. 

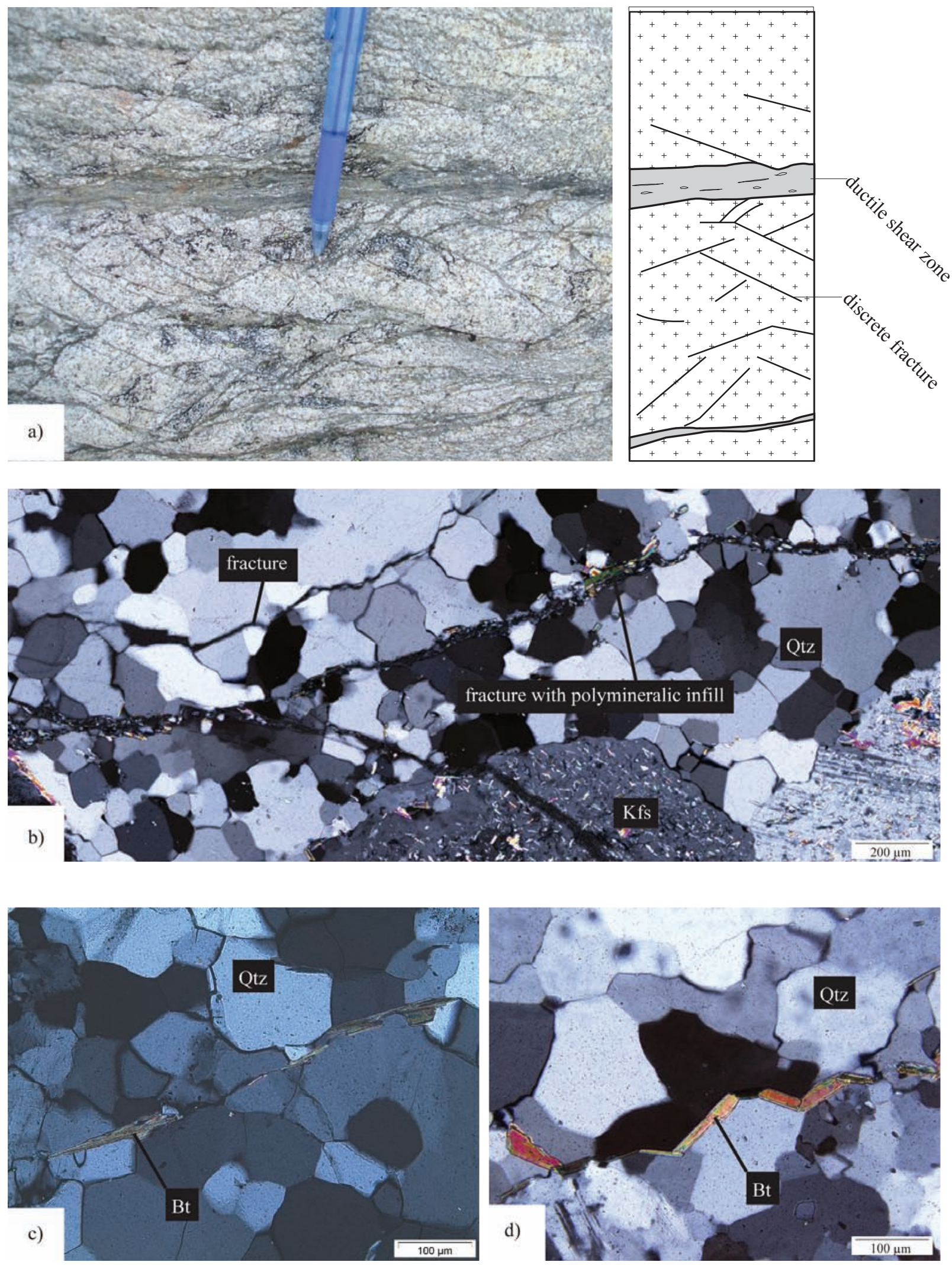

Fig. 7: (a) Field photo (left) and sketch (right) from a ductile shear zone cutting discrete fractures in the weakly deformed Central Aare-granite (CAGr). (b) Micrograph of brittle fractures cutting a monomineralic dynamically recrystallized ductile quartz (Qtz) fabric. Bourder is shown by K-feldspar crystals (Kfs). Some fractures show a polymineralic infill. (c,d) Detail of a transgranular (c) and intergranular fracture (d), where biotite (Bt) has precipitated, within a dynamically recrystallized monomineralic quartz domain (samples 12.004H-UR and gts 1; see Table 2). 


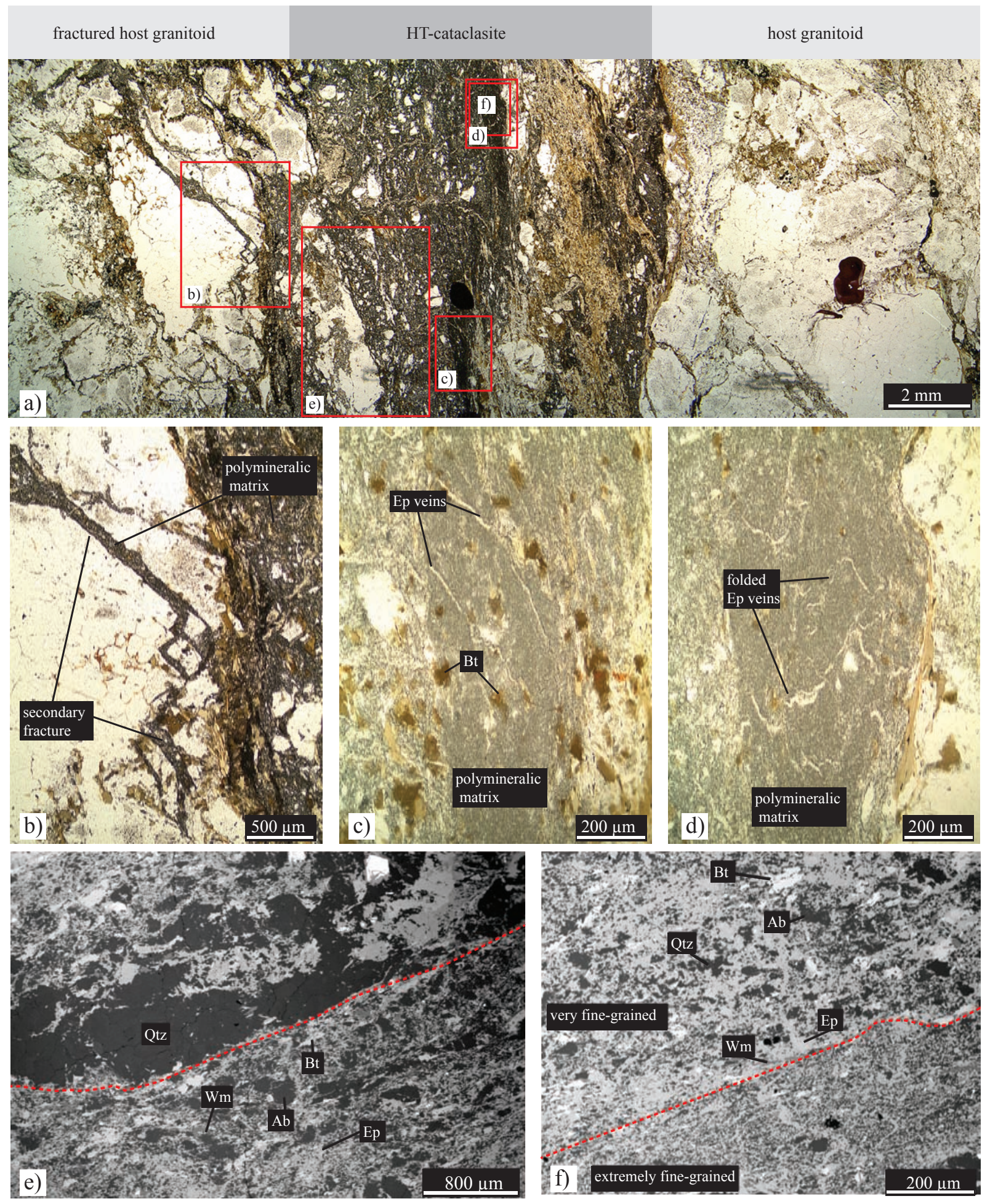

Fig. 8: (a-d) Micrographs of a HT-cataclasite from the Grimsel Zone (Sample GR47; Table 2). (a) Overview, where cataclasites cut through the host granitoid. Rectangles in (a) indicate locations of figures (b-f). (b) Detail showing secondary fractures with injections of the extremely fine-grained polymineralic matrix. (c) Detail of the extremely fine-grained polymineralic matrix with overgrowing biotite and epidote veins. (d) Micro-epidote veins are folded within the polymineralic matrix. (e,f) Backscatter electron images of the contact (stippled) between the polymineralic matrix and the weakly deformed host (e) and an ultrafine-grained, polymineralic matrix (f). (Wm: white mica, Qtz: quartz, Ab: Albite, Ep: Epidote, Bt: biotite) 


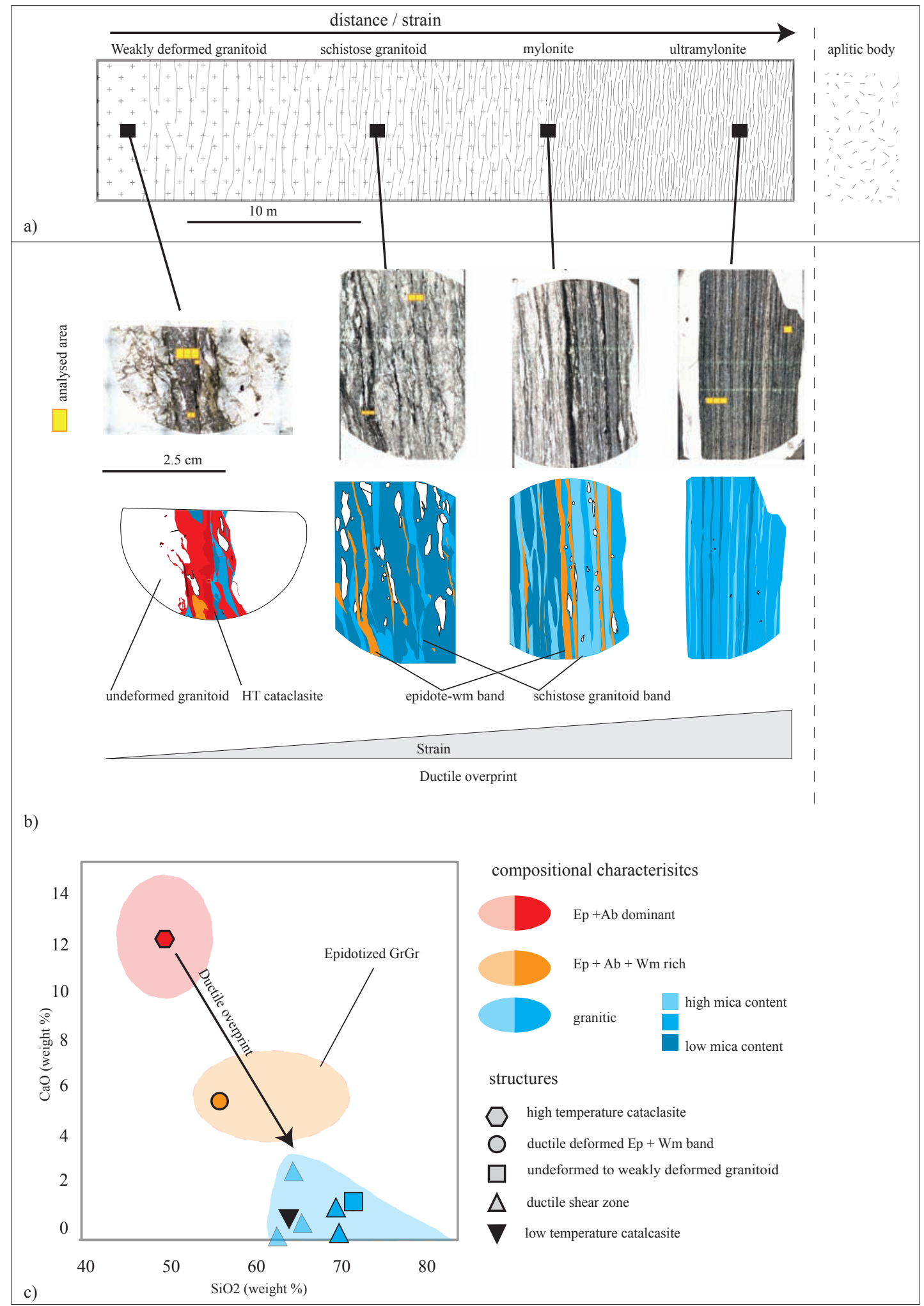

Fig. 9: (a) Sketch of the strain gradient in a fault zone at the contact of the Grimsel Zone to the aplitic body (top row), photographs of the analyzed samples (central row) and corresponding spatial distributions of isocompositional domains (bottom row; for color code see legend in (b)). Indicated are the locations of the samples along the strain gradient and the analysis areas on the samples (Sample Serie from Swiss-coord. 668890/157144 to $668942 / 157227$, see also Table 2). (b) Harker diagram for $\mathrm{CaO}$ to SiO2 wt.\% data from this study (solid symbols) in combination with literature data (transparent symbols) from Goncalves et al. (2012) and Keusen et al. (1989). Data has been separated on the basis of structures. Additionally, three groups of similar $\mathrm{CaO}$ content exist. Note that the mylonites and host rock fall within a domain of similar composition although mica content may vary as observed in (a). The transparent area in the graph represents the total range of compositions, which in case of the HT-cataclasite is given by the spread within own measurements. Noteworthy is also the epidotized GrGr sample from Keusen et al. (1989), which shows some similarities with our sample from the Grimsel Zone. 


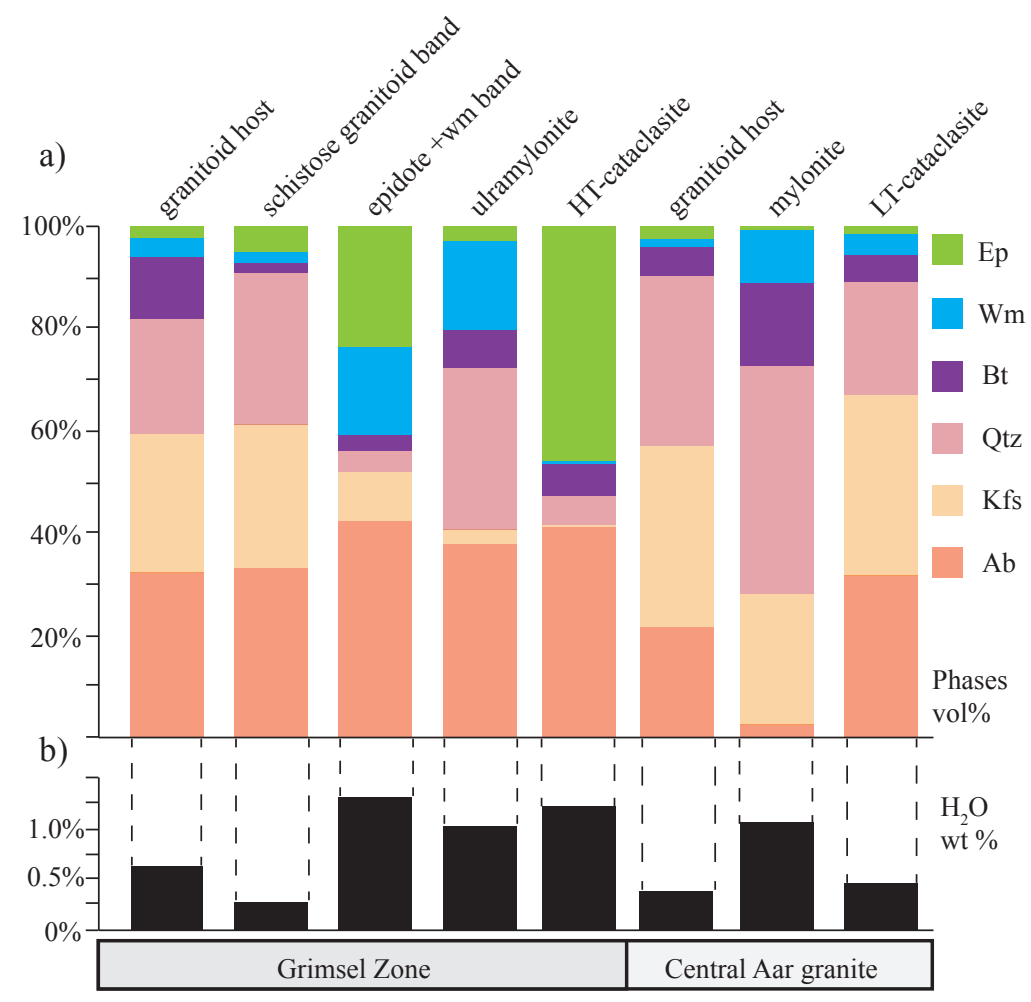

Fig. 10: Area percentages of different phases (a) and the resulting water content $(b)$ for each structure and a reference granitoid host within both Central Aar granite and Grimsel Zone. 

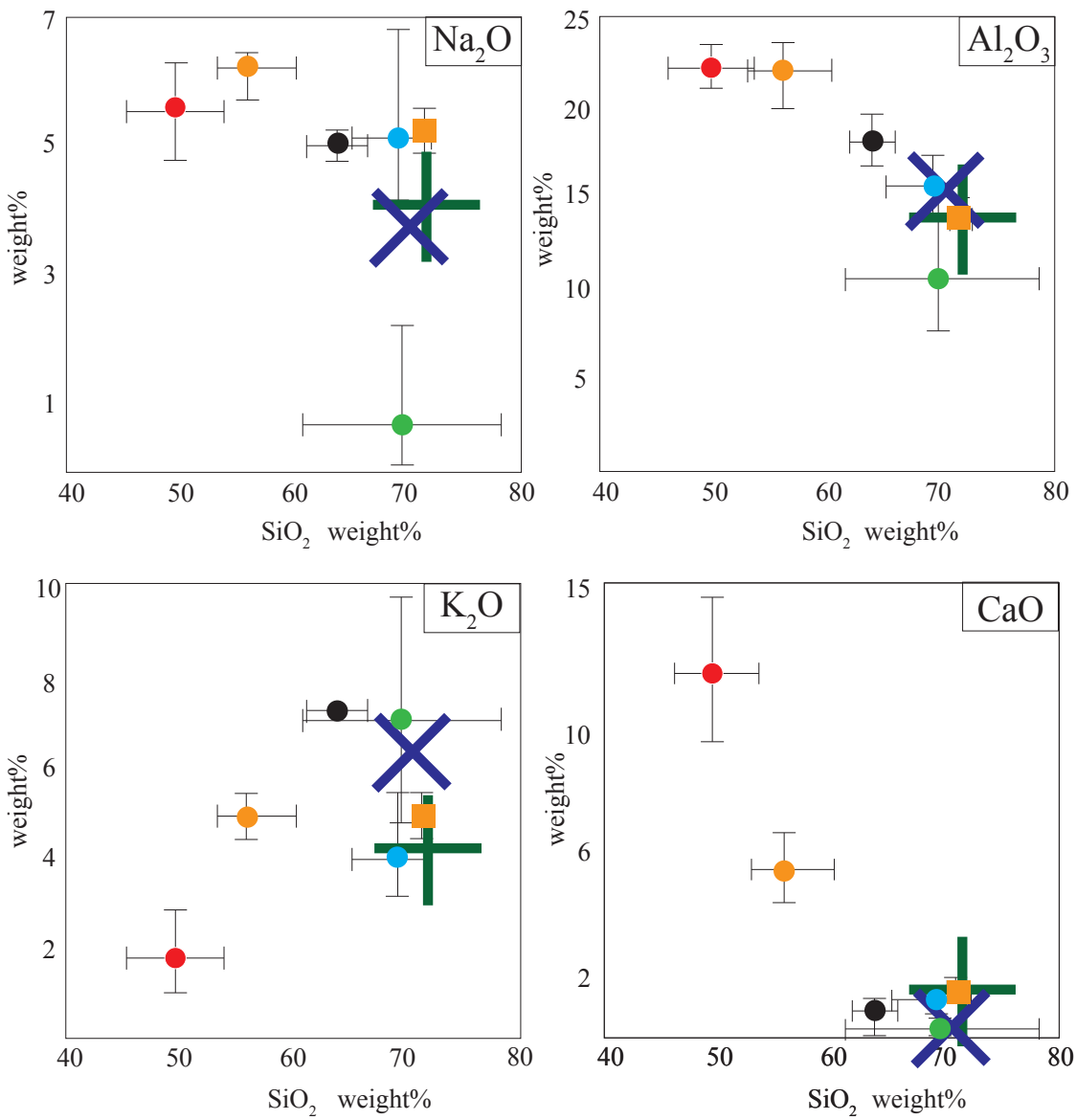

- HT-cataclasite (GZ)

mylonite (CAGr)

- schistose granitoid band (GZ)

- LT-cataclasite (CAGr)

Ep + Wm band (GZ)

CAGr (Keusen avg.)

- ultramylonite (GZ)

- GZ (Stalder calculated)

Fig. 11: Harker diagrams for each structure and the host granitoid for (a) $\mathrm{Na}_{2} \mathrm{O}$, (b) $\mathrm{Al}_{2} \mathrm{O}_{3^{\prime}}$ (c) $\mathrm{K}_{2} \mathrm{O}$ and (d) $\mathrm{CaO}$. Data points are representative averages for each structure. The bars in the Harker diagram show the total spread in analysed data with respect to the representative average. 


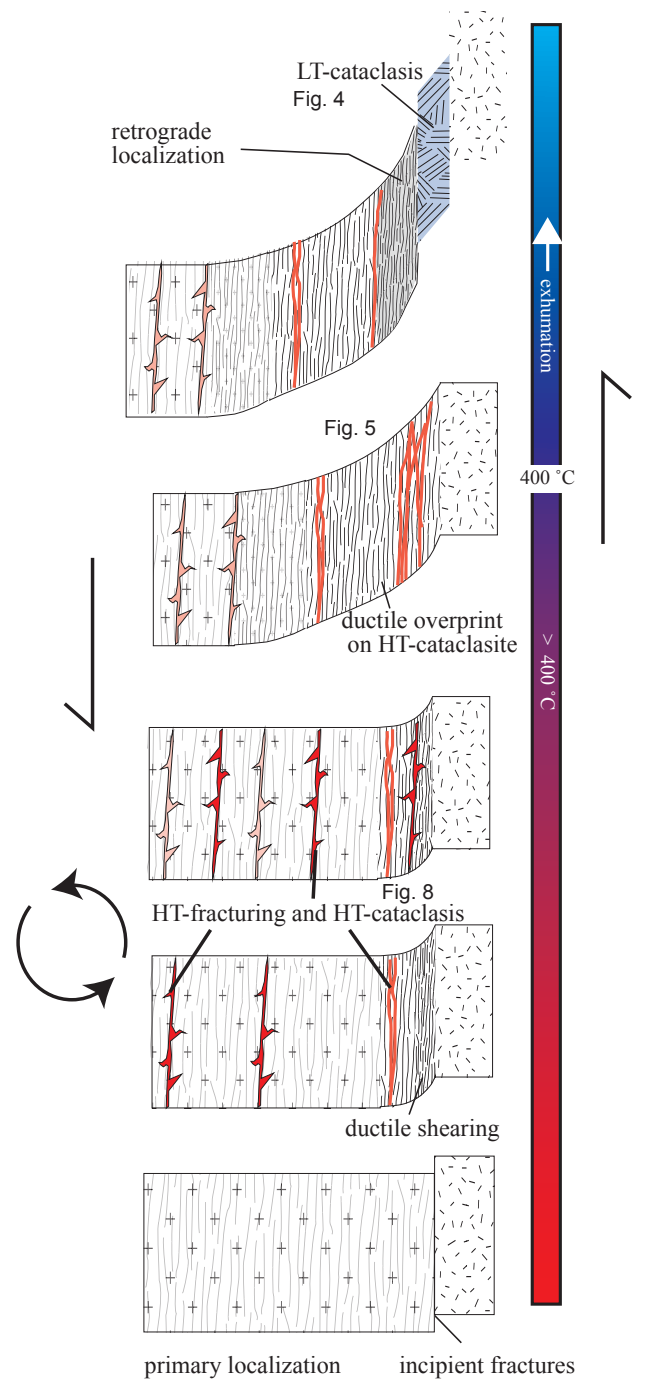

Fig. 12: Structural evolution between frictional and viscuous deformation and its cyclcic behaviour. Compare figures 4, 5 and 8 for the observed microstructures. 


\section{a) monomineralic}
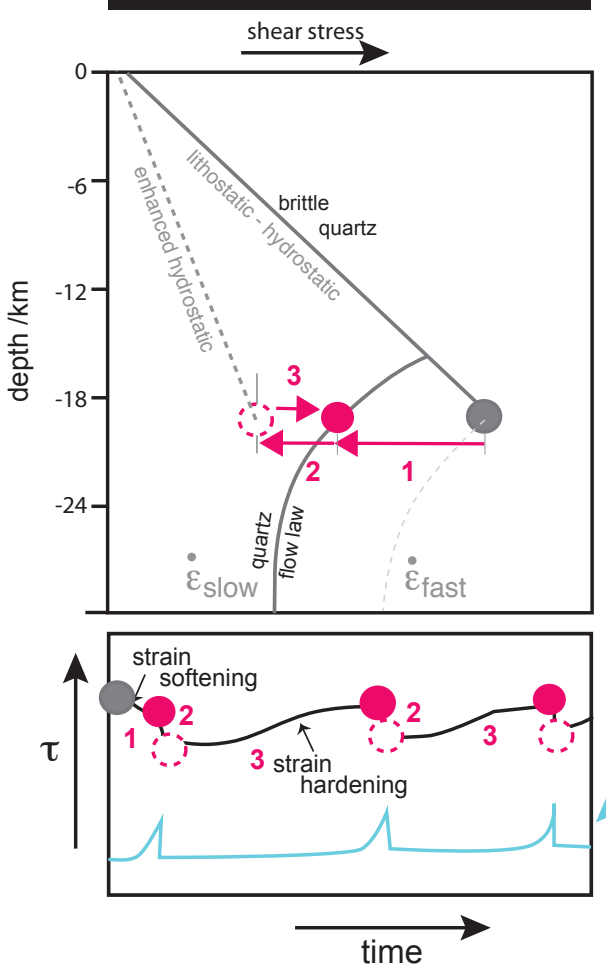

1 dynamic recrystallization (Figs 6 and 7 )

2 hydrofracturing

biotite precipitation (Fig. 7c)

3 dynamic recrystallization

dislocation creep (Figs. 5d, 6)

\section{b) polymineralic}
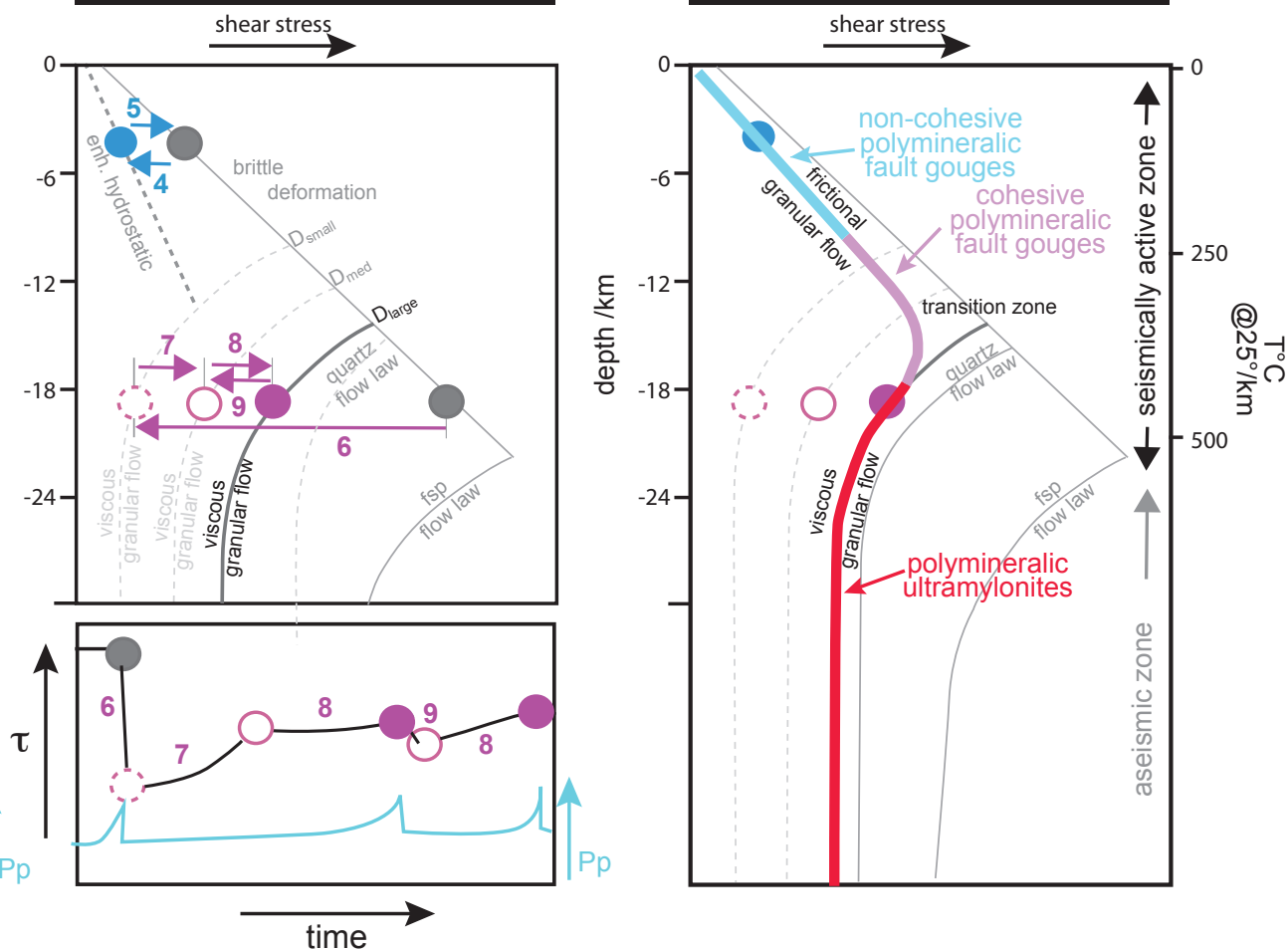

4, 5 LT-cataclasite (Fig. 4)

6 HT-cataclasite

injection of non-cohesive gouge (Fig. 8b)

7 coupled grain coarsening

and viscous granular flow (Fig. 5)

8 viscous granular flow and grain coarsening

9 hydrofracturing

Fig. 13: Linking microstructures with rheological profiles (a) the theoretical evolution for quartz: Upper diagram shear stress verses depth; lower diagram shear stress and fluid pore pressure versus time. (b) the theoretical evolution for granitoid bulk rock: same type of diagrams as in (a). (c) a conceptual model for granitoid rheology and the FVT 


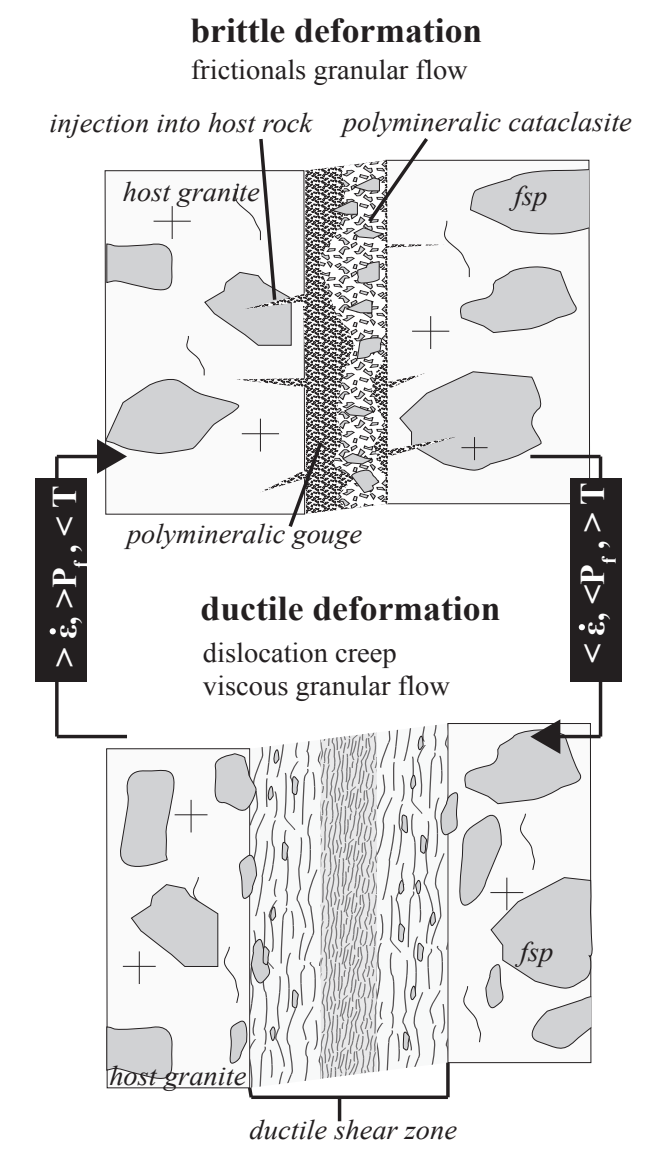

a)

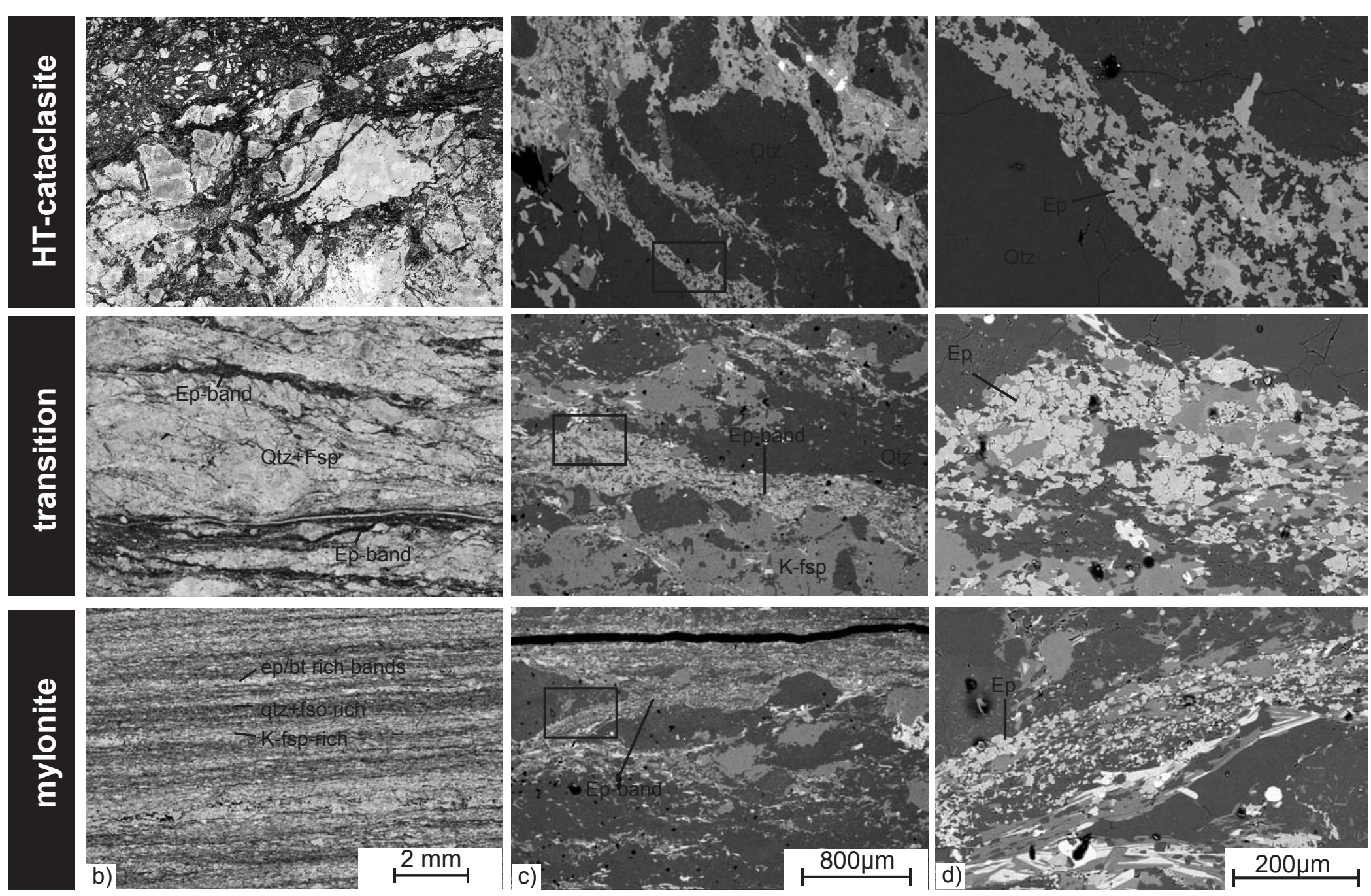

Fig. 14: Overview of the FVT transition and the role of chemical differences in a continuous process. (a) sketch showing the relationship between strain rate, temperature and fluid pressure and the deformation processes. (b) column of microphotographs in corssed polarized light, (c) BSE overview images, (d) Zoom-in from column (c) showing detail structures (BSE-images). First row show the HT-catalcaslites with fracturing producing injection veins rich in Epidote (see also Fig. 8). Second row show intermediate stage developing bands out of the injected Ep/Ab bands. Third row show the mylonitic structure with some relics of such Ep-rich bands. Compare also figure $9 \mathrm{~b}$. 
Table 1: Summary of grain sizes. Measurements are done on representative 20-50 grains per group. Data are given in $\mu \mathrm{m}$

\begin{tabular}{|c|c|c|c|}
\hline Fault rocks & feldspar & quartz & mica \\
\hline Host rocks & $500-20000$ & 180 & $*$ \\
\hline $\begin{array}{l}\text { low temp. } \\
\text { cataclasite: } \\
\text { clasts }\end{array}$ & $50-500$ & $35-350$ & $35-500$ \\
\hline matrix & $1-5$ & $1-5$ & $1-5$ \\
\hline $\begin{array}{l}\text { high temp. } \\
\text { cataclasite: } \\
\text { clasts }\end{array}$ & $100-300$ & $60-150$ & - \\
\hline matrix & $*$ & $1-5$ & $1-5$ \\
\hline $\begin{array}{l}\text { Mylonite: } \\
\text { clasts } \\
\text { matrix }\end{array}$ & $\begin{array}{c}150-300 \\
10-80\end{array}$ & $\begin{array}{c}- \\
10-80\end{array}$ & $\begin{array}{c}3-150 \\
\sim 50\end{array}$ \\
\hline
\end{tabular}

- not existing; *: not measured 
Table 2: Location of key samples

\begin{tabular}{lllcccc}
\hline sample & Type & location & Swiss Koord & $\begin{array}{c}\text { Chemical } \\
\text { data in Figs. } \\
9,10 \text { and 11 }\end{array}$ & $\begin{array}{c}\text { Grain } \\
\text { sizes } \\
\text { Table 1 }\end{array}$ & EBSD \\
\hline 11.004VURc & LT catacl. & GTS & 667584159912 & $\mathrm{x}$ & $\mathrm{x}$ \\
GTS1100 & mylonite & GTS & 667584159912 & $\mathrm{x}$ & $\mathrm{x}$ & \\
GR47 & HT-catacl. & Grimsel pass & 668890157144 & $\mathrm{x}$ & $\mathrm{x}$ & \\
Gr45 & schistose band & Grimsel pass & 668921157178 & $\mathrm{x}$ & & \\
Gr43.1 & ultramylonte & Grimsel pass & 668942157227 & $\mathrm{x}$ & & $\mathrm{x}$ \\
Gr10 & mylonite & Bächli area & 664650159825 & & & \\
\hline
\end{tabular}

